Environmental Science and Pollution Research (2015) vol 22 pp 13577-13598

\title{
Environmental microbiology as a mosaic of explored ecosystems and issues
}

Denis Faure ${ }^{1} \&$ Patricia Bonin ${ }^{2,3}$ \& Robert Duran ${ }^{4}$ \& the Microbial Ecology EC2CO consortium

Corresponding authors: Denis Faure (denis.faure@i2bc.paris-saclay.fr) and Patricia Bonin (patricia.bonin@mio.osupytheas.fr)

1- Institut de Biologie Intégrative de la Cellule, CNRS-CEA-Université Paris-Sud, Saclay Plant Sciences, 91198 Gif-sur-Yvette cedex, France

2- Aix-Marseille Université, Mediterranean Institute of Oceanography (MIO), 13288 Marseille, Cedex 9, France

3- Université du Sud Toulon-Var, CNRS-INSU/IRD UM 110, 83957 La Garde, France

4- Equipe Environnement et Microbiologie, MELODY group, Université de Pau et des Pays de l'Adour, IPREM UMR CNRS 5254, BP 1155, 64013 Pau Cedex, France

\begin{abstract}
Microbes are phylogenetically (Archaea, Bacteria, Eukarya, and viruses) and functionally diverse. They colonize highly varied environments and rapidly respond to and evolve as a response to local and global environmental changes, including those induced by pollutants resulting from human activities. This review exemplifies the Microbial Ecology EC2CO consortium's efforts to explore the biology, ecology, diversity, and roles of microbes in aquatic and continental ecosystems.
\end{abstract}

\section{Keywords}

Environmental microbiology ; Microbial ecology ; Critical zone ; Microbial ecosystems

\section{Introduction}

Environmental microbiology deals with microbial life on Earth: Bacteria, Archaea, and unicellular Eukaryotes, as well as viruses. Investigations on the microbial diversity include questions on dynamics, adaptation, functioning and roles of individuals, populations and communities, and their interactions with biotic and geochemical components of ecosystems.

For several years, the French initiative Ecosphère Continentale et Côtière (EC2CO), coordinated by the Centre National de la Recherche Scientifique (CNRS), has been promoting innovative, disciplinary, or interdisciplinary starting projects on the continental and coastal ecosystems (http:// www.insu.cnrs.fr/node/1497). Within EC2CO, the environmental microbiology action called MicrobiEn aims at identifying and supporting scientific projects at the interfaces between microbial ecology, geochemistry, hydrology, ecotoxicology, biological interactions, and diversity as well as modeling in order to understand the role of microbes in the Earth critical zone.

Four thematic approaches have been developed within the MicrobiEn action: (1) diversity and dynamics of microbial populations and communities including analysis, management, and preservation 
of microbial diversity as well as the consequences of environmental (local factors) and climatic (global factors) changes on the functional biodiversity and functioning of microbial ecosystems; (2) microbes and geochemical cycles, i.e., the role of microbial diversity in ecosystem functioning and regulation of biogeochemical cycles, including the identification of markers to assess the functioning of ecosystems; (3) microbe-microbe and host-microbe interactions, i.e., the mechanisms of interaction between microorganisms or between microorganisms and other organisms such as plants or animals, the molecular means of communication between microorganisms (e.g., allelopathy and quorum-sensing), and the characterization of obligatory or nonobligatory symbiotic equilibria (parasitism, commensalism, mutualism, cooperation); (4) microbes and pollutants, i.e., the impact of emerging pollutants, multi-pollution, chronic diffuse pollution, and global changes on the functioning of microbial ecosystems with a special interest in the role of microorganisms in transforming and determining the fate of pollutants and eco-toxicological state of the environments.

This review illustrates the collective efforts made by the Microbial Ecology EC2CO consortium and by the Microbial Ecology EC2CO scientific committee to explore the microbial world from an environmental point of view. The contributions which were collected from around 60 starting projects are organized in four sections: (1) "Diversity and dynamics of microbe populations and communities," (2) "Geochemical cycles: role and functioning of microbial communities," (3) "Microbe-microbe and host-microbe interactions," and (4) "Pollutants and microbes."

\section{Diversity and dynamics of microbe populations and communities}

Continental and aquatic environments exhibit a wide variety of physical and biological parameters, which impact the structure and dynamics of microbial communities.

Microbes are key components of aquatic systems in terms of abundance, biomass, and functional roles. Although extensively studied in marine environments and lakes, little is known about their diversity and ecology in small and shallow freshwater ecosystems (from 0.001 to $0.1 \mathrm{~km}^{2}$ in size), though they are widespread and represent up to $99 \%$ of the total number of lakes on Earth. Molecular diversity of protists ( 0.2 to $5 \mu \mathrm{m}$ in size) was investigated using pyrosequencing of amplified $18 \mathrm{~S}$ rRNA gene fragments, for 2 years in four ponds and one brook (" Parc Naturel Regional de la Haute Vallée de Chevreuse " France) revealing a high diversity of small protists, composed of as much as 3,742 stringently defined operational taxonomic units (OTUs). They belong to all recognizedeukaryotic supergroups (Stramenopiles-AlveolataRhizaria, Archaeplastida, Excavata, Amoebozoa, Opistokonta) but also to groups of unresolved phylogenetic position (Cryptophyta, Haptophyta, Centrohelida, Katablepharida, Telonemida, Ancyromonadida, Apusozoa) (Simon et al. 2013, 2015). Remarkably, several lineages which were previously thought to be marine (e.g., MAST-3 and possibly MAST-6 groups) were identified in the studied ecosystems when, inversely, some OTUs were only detected in freshwaters (e.g., HAP-1 of the haptophytes) (Simon et al. 2014). Only 50 OTUs were shared by the five ecosystems studied. The difference of the protist community structure between the ecosystems studied did not seem to be linked to the geographical distances but instead to environmental 
parameters. Low-abundance OTUs that dominated the community either appeared occasionally or persisted at low frequencies. This suggests that part of them constitutes a seed bank. While high-rank taxa were characterized by a complex temporal dynamics, a clear seasonal pattern was observed (Simon et al. 2015). In lakes and reservoirs, phytoplankton community structure results primarily from interactions between physical forcing and biological response at a variety of time scales (Pannard et al. 2008). However, the role of habitat fragmentation, frequency, and intensity of hydrodynamic exchanges on the global phytoplankton diversity remains largely unexplored. Especially, the following hypothesis could be tested in the aquatic ecosystems: that diversity ensures the functioning of the ecosystem by the spatial insurance resulting from exchanges between microhabitats within heterogeneous systems.

In coastal environment, a fresh insight into the diversity and functionality of intertidal purple sulfur bacterial mats was proposed (Hubas et al. 2011, 2013). Different types of purple sulfur microbial mats were examined using taxonomical and physiological biomarkers (fatty acids, photosynthetic pigments, as well as rrs and pufM genes). Sediment surface adhesion (a proxy for sediment stability) and carbon fluxes were also measured as ecosystem processes. A new method based on spectral reflectance was developed for the study of purple bacterial mats, a promising tool for a true integration of these systems on larger scales (Hubas et al. 2011). Microbial assemblages were dominated by purple sulfur bacteria (Chromatiaceae), which are great exopolymer producers suggesting that their impact on intertidal sediments stability is significant. These carbonsecretionsare concomitant with high respiration rates indicating that despite an apparent $\mathrm{CO}_{2}$ fixation and a high pigment synthesis, these bacteria could develop a heterotrophic metabolism instead of a phototrophic metabolism (Hubas et al. 2013). Finally, nanoscale fixation of organic and inorganic carbon and nitrogen by purple sulfur bacteria and implications for coastal carbon cycles were evidenced by mass spectrometry of secondary ions allowing to determine the rate of carbon and nitrogen fixation at the cellular level.

Coral reefs are among the most vulnerable marine ecosystems and have declined dramatically over the last 30 years owing to the combined effect of global warming and increasing anthropogenic pressure. The first signs of this decline are coral bleaching and the emergence of new pathologies, which now affect coral reefs throughout the world. A recent hypothesis considers that such pathologies might be the result of a sudden structural alteration of the epibiotic bacterial communities in response to environmental disturbances. However, little is known about the ecological mechanisms that lead to the effective replacement of these communities. In the ocean's water column, viruses represent a prominent source of control of bacterial communities. However, their occurrence and role within the coral holobiont have not yet been evaluated and could be pivotal for coral health. The main ecological traits (abundance, life strategies, and diversity) of coral-associated viral communities were investigated. A combination of fieldwork and experimental studies was conducted from corals collected in the Bay of Nha Trang (Vietnam). A standardized protocol to extract and enumerate viruses from coral mucus was developed (Leruste et al. 2012) revealing that mucosal viruses were highly abundant, mostly comprised of phages and produced from lytic infection of the most active fraction of the bacterial associates (Bettarel et al. 2013; Nguyen et al. 2014). Finally, these results suggest that viruses could be decisive for coral health and for the stability of reef ecosystems (Bettarel et al. 2015). 
Another major process involved in coral reef maintenance is the process of carbonate biogenic dissolution driven by microboring organisms, which comprise unicellular and filamentous cyanobacteria, algae, and fungi (Verbruggen and Tribollet 2011). The bioeroding chlorophyte of the genus Ostreobium sp., the main agent of this process, appears to be the mostresponsivemicroboringspecies tothose environmental factors (Tribollet et al. 2009). Ostreobium recruitment period, its development along community successions, the impact of its dynamics on rates of biogenic dissolution, and how it is affected by environmental factors remain, however, poorly known. An experiment was thus carried out on a reef in New Caledonia to study with a monthly resolution, Ostreobium's ecology, microboring community successions and biogenic dissolution dynamics over time. The results showed that microboring communities at their early developmental stage were dominated by large chlorophytes that induced low rates of biogenic dissolution. Then, between 3 and 6 months, the chlorophyte Ostreobium started dominating communities, which consequently increased rates of carbonate dissolution. Finally, after 6 months of exposure, Ostreobium-dominated communities and biogenic dissolution reached a "plateau " with some variations resulting from the grazing pressure (Grange et al. 2015). Results highlight that both studied biotic and abiotic factors influenced greatly microboring communities' dynamics. The observations suggested that global warming combined with ocean acidification and/or eutrophication may increase greatly biogenic dissolution of reef carbonates and therefore accelerate the shift from net reef calcification towards net reef dissolution.

In the Mediterranean Sea, the cryptic invasive dinoflagellates Alexandrium catenella (group IV-toxic) and Alexandrium tamarense (group III-nontoxic) are listed as exotic or non-indigenous phytoplankton and tagged by the International Union for the Conservation of Nature (IUCN). These species, spread in the Western Mediterranean region along French, Spanish, Italian, and Maghrebian coasts, cause damages to shellfish farming and tourism activities (Anderson et al. 2012). The genetic diversity and physiological variability of these species were investigated to understand the dynamics of their invasion process and their maintenance in the Mediterranean coastal areas. The occurrence of $A$. catenella related to paralytic shellfish poisoning in the French Mediterranean Thau Lagoon has been known since 1998. Blooms are recurrent and usually occur each year in spring and/or autumn.

The presence of $A$. tamarense (group III) species in water and sediment of Thau Lagoon was recently discovered by large scale cultivation and semi-multiplex PCR (Genovesi et al. 2011). A single-cell technique was developed for a taxonomic characterization of these two species to skip the long and tedious cultivation procedure (Masseret et al. 2010). A population genetics study comparing the French and Japanese strain diversity showed that the French population belonged to a new lineage separated from the Asian (Masseret et al. 2009). Characterization of physiological parameters was performed on several $A$. catenella and $A$. tamarense monoclonal cultures in order to better understand their ability to nutritional adaptation and their toxinic features in relation with environmental conditions (Collos et al. 2011; Laabir et al. 2012; Hadjadji et al. 2012). Finally, 12 new microsatellite markers weredeveloped tobetterdescribethe genetic diversity ofthese two species in the Mediterranean Sea and over the world (Laporte et al. 2014). 
A fascinating coastal ecosystem had been recently discovered: the Prony hydrothermal field in New Caledonia. Thisis a shallow-sea, serpentinite-hosted alkaline hydrothermal vent system. Serpentinization, hydrous alteration of ultramafic rocks, and associated geochemical reactions are important sources of energy and organic carbon for subsurface habitats, but very few studies have explored the distribution, ecology, and evolution of serpentinite-hosted microbial communities. Pioneering researches have shown that the Prony hydrothermal field discharges warm (up to $43^{\circ} \mathrm{C}$ ), alkaline (up to $\mathrm{pH} \sim 11.4$ ), $\mathrm{H}_{2}$, and $\mathrm{CH}_{4}$ enriched fluids into the ocean, resulting in upto 38-m-high calcite/brucite towers (Monnin et al. 2014). Hence, the Prony hydrothermal field resembles the so far beststudied site of Lost City, near the Mid-Atlantic Ridge. However, it also exhibits similarities to many terrestrial springs because fluids are sourced in meteoric water and discharge occurs within the photic zone. Intriguingly, the first microbiological studies, using both cultural and molecular-based methods, revealed that microbial communities in Prony chimneys have similarities to both the deep sea of Lost City and the terrestrial Cedars site (Quéméneur et al. 2014). However, some alkaliphilic microorganisms were only found in the Prony hydrothermal field. Hydrogen and methane produced by serpentinization reactions seem to be the primary sources of energy of the microbial ecosystem inhabiting the chimney of the Prony hydrothermal field.

For the detection and rapid enumeration of heterotrophic flagellates in coastal environments, an alternative method to microscopy was developed using cytometry (Christaki et al. 2011). Two approaches are provided: (1) measuring overall abundance by flow cytometry and (2) detection of groups and species-specific solid phase cytometry (ChemScan) on cells labeled with Molecular Probes (FISH). These protocols were applied on samples collected at monitoring stations in coastal waters of the Mediterranean Sea and the Eastern Channel. The method and its limitations were extensively tested using a wide range of sample types and trying several fixation and conservation alternatives. Some steps were simplified. The seeking seemed the best compromise between precision and the quality of distinction of heterotrophic flagellates from bacteria and phytoplankton in the cytograms. No significant differences were found between cell numbers obtained from freshly analyzed samples and those previously frozen in liquid nitrogen. Flow cytometry and epifluorescence microscopy were in good agreement, and heterotrophic flagellates yielded lower variability between replicate samples than epifluorescence microscopy. One limitation was that, in the presence of large bacteria and/or bacterial aggregates, enumeration was difficult. However, in absence of bacterial aggregates, heterotrophic flagellates could be well enumerated.

The diversity and seasonal variability of nano- and microeukaryotes and their significance were investigated in a productive ecosystem in which heterotrophic eukaryotes regulate bacterial and phytoplankton production playing therefore a key role in carbon transfer. The succession of planktonic unicellular eukaryotes was explored by means of 18S rRNA gene tag pyrosequencing in the eastern English Channel during the winter to summer transition (Monchy et al. 2012; Christaki et al. 2014). The 59 most representative ( $>0.1 \%$, representing altogether $95 \%$ of total reads), unique OTUs from all samples belonged to 18 known high-level taxonomic groups and one unaffiliated clade. The five most abundant OTUs (69.2 \% of total reads) belonged to Dinophyceae, Cercozoa, Haptophyceae, Marine Alveolate group I (MALV-I), and Fungi. Cluster and network analysis between samples distinguished 
the winter, the pre-bloom, the Phaeocystis globosa bloom, and the post-bloom early summer conditions. The OTU-based network revealed that $P$. globosa showed a relatively low number of connections-most of them negative-with all other OTUs. Fungi were linked to all major taxonomic groups, except Dinophyceae. Cercozoa mostly co-occurred with the Fungi, the Bacillariophyceae, and several of the miscellaneous OTUs. Thus, a more detailed exploration into the planktonic succession pattern of the eastern English Channel was provided thanks to increased depth of taxonomic sampling over previous efforts based on classical monitoring observations. Data analysis implied that the food web concept in a coastal system based on predator-prey (e.g., grazer-phytoplankton) relationships is just a part of the ecological picture, and those organisms exploiting a variety of strategies, such as saprotrophy and parasitism, are persistent and abundant members of the community.

Aquatic viruses infecting picophytoplankton are highly diverse assemblages dynamically interconnected with their hosts, playing a major role in nutrient recycling and on global biogeochemical cycles. However, the spatiotemporal distribution and diversity of viral populations are still not well known, as well as the factors controlling this diversity. Two studies focused on the genus Prasinovirus, giant dsDNAviruses from the Phycodnaviridae family which infect an abundant and widespread picoeukaryotic algal class, the Mamiellophyceae (Clerissi et al. 2014a, b). Several complete genomes are available for Prasinoviruses; they have been used to define suitable molecular markers to investigate the diversity of these viruses.

A genetic fingerprinting assay using terminal restriction fragment length polymorphism(T-RFLP) wasdeveloped allowing a rapid evaluation of the diversity of Prasinoviruses in a large number of samples from five stations representing contrasted environments (lagoon vs open sea) in the Gulf of Lion (Mediterranean Sea, SE France). Pyrosequencing was also performed for a more in-depth characterization of the viral diversity in an attempt to link the viral diversity to environmental variables measured at each sampling site. During a year, the diversity of Prasinovirus assemblages differed between lagoon and open sea suggesting that the environment, particularly seasonality, shapes Prasinovirus communities. The main result is that nutrients, especially phosphates, strongly affect Prasinovirus populations, which has been related to the importance of this element for viral genome synthesis (Clerissi et al. 2014a).

In the deep-sea waters, several organisms, including bacteria, produce bioluminescence (Martini et al. 2013). The Astronomy with an Neutrino Telescope and Abyss environmental RESearch (ANTARES) telescope immersed in the Mediterranean Sea at 2,475-m depth has been used as an oceanographic observatory recording bioluminescence as well as environmental variables at high frequency. This time series analysis, defined as non-linear and non-stationary, highlighted two periods of highbioluminescence intensity in 2009 and 2010. These events have been explained by convection phenomena in the Gulf of Lion, indirectly impacting the bioluminescence sampled at this station (Tamburini et al. 2013; Martini et al. 2014). In parallel, laboratory experiments have been done in order to reproduce the in situ conditions (low temperature, high temperature) encountered into the deep ocean (Martini et al. 2013). Bacterial bioluminescence has been studied using a piezophilic bacterial model (Photobacterium phosphoreum ANT-2200) isolated during a high-bioluminescence intensity event at the ANTARES site and recently sequenced (Zhang et al. 2014). Hydrostatic pressure linked to 
the in situ depth (22 $\mathrm{MPa}$ ) induces a higher bioluminescence activity than under atmospheric pressure (0.1 MPa) as well as a better growth at $22 \mathrm{MPa}$ than at $0.1 \mathrm{MPa}$ (Martini et al. 2013). Over the year 2011, the survey of the deep prokaryotic communities at the ANTARES station showed the presence of about 0.1 to $1 \%$ of bioluminescent bacteria even during a low-bioluminescence-activity period. These cells were mainly actives. The innovative nature of this work was based on the use of a neutrino telescope as a deep-sea observatory to measure a biological activity, the bioluminescence.

A challenge is to understand and predict how biological systems respond to environmental changes, both in the short and long term. Glycerol dialkyl glycerol tetraethers (GDGTs) are membrane lipids produced by archaea and some unknown bacteria. The chemical structure of these compounds is related to environmental parameters, mainly air temperature and $\mathrm{pH}$. Therefore, they can be used to reconstruct past climate changes. Nevertheless, to date, the applicability of GDGTs as a temperature proxy has been mainly investigated in soils and marine environments and needs to be further examined in lakes. The lake Masoko is located at $840 \mathrm{~m}$ altitude at Mt. Rungwe (Tanzania). The comparison of GDGT abundance and distribution in soil, suspended material (collected at 5-, 18-, and 33-m depth), and sediment samples (36-m depth) showed that these compounds are mainly produced in situ, in the water column, and/or sediment. In addition, analysis of GDGTs in ca. 20 soils collected along Mt. Rungwe between 500 and $2800 \mathrm{~m}$ altitude confirmed that GDGTs of bacterial origin are robust temperature proxies in the region. This work reveals that archaeal GDGTs, which were mainly studied in aquatic environments until now, could also be used to track environmental changes in terrestrial settings (Coffinet et al. 2014).

An experimental microcosm approach was setup to study the short-term combined action of biotic and abiotic stresses on microbial community dynamics. For the protozoan Paramecium caudatum, it was demonstrated that infection with a parasitic bacterium generally reduces tolerance to heat and osmotic stress. Effects varied considerably with host genotype, suggesting that parasite-mediated selection can be highly context-dependent (Duncan et al. 2010). Duncan et al. (2011a) further studied epidemiology along a temperature gradient, with either constant or variable temperatures, changing between $23{ }^{\circ} \mathrm{C}$ (permissive) and $35^{\circ} \mathrm{C}$ (stressful). Variable temperature increased negative effects of the parasite on host density but also reduced parasite persistence, illustrating the idea that marginal habitats may represent parasite-free refuges. Corroborating basic theory, Duncan et al. (2011b) showed that Paramecium evolved specialist types under constant temperature and generalists under variable temperature. These results emphasize the need to consider environmental variance, as well as means, when predicting impacts on species range. Anthropogenic change can also impact resource availability and hence community productivity. A study on a natural bipartite soil network between bacteria and lytic bacteriophages showed that low-resource conditions decrease phage generality and reduce community robustness and stability (Poisot et al. 2010). This corroborates the general prediction that environmental perturbation affects community complexity. Bacterial communities may respond to stress through (co)evolution but also through plasticity. Using Pseudomonas fluorescens and its bacteriophage $\Phi 2$, Poisot et al. (2013) demonstrated an inducible response via a transient increase in population growth rate, induced by phage binding. A concomitant decrease in bacterial cell 
size indicated an associated fitness cost. These results have important implications for bacterial ecology and phage- bacteria co-evolution in soil communities.

\section{Geochemical cycles: role and functioning of microbial communities}

Microorganisms form the backbone of every ecological system by controlling global biogeochemical cycling of elements essential for life such as $\mathrm{C}, \mathrm{N}$, or P but also Fe or $\mathrm{Mn}$.

Different levels of complexity may impact the diversity- productivity relationship. It can be hypothesized that synergistic or antagonistic effects (i.e., competition) exist among key soil microorganism categories, such as arbuscular mycorrhizal fungi, nitrogen-fixing bacteria, ammonium oxidizers, and organic matter decomposers, which regulate nitrogen cycling in ecosystems. As a consequence of these hypotheses, an emerging idea would be the possible microbial mediation of functional equilibrium. The acquisition of new understanding on the link between diversity and ecosystems functioning is the major challenge in microbial ecology.

Studies on plant-driven microbial functioning and selection by secondary metabolites often focused on the effect of plant on the nitrogen cycle. In a recent work, the role of plants on biological denitrification inhibition (BDI) was revealed (Bardon et al. 2014). The invasive complex species Fallopia sp. was shown to reduce denitrification, a major way of nitrogen loss by gaseous emission, in soil. The identification of involved compounds in this BDI, their action mechanisms, and ecological consequences for plant growth are being investigated on a panel of cultivated strains and on a complex microbial community in soil by comparing effects of root extracts from Fallopia on metabolic activity and respiratory activity, in aerobic condition, and anaerobic condition (denitrification). The analysis of root extracts shows the presence of families of compounds recognized for their biological activities. Indeed, on denitrifying bacteria, denitrification inhibition (95\%) by root extracts from Fallopia sp. is higher than respiration inhibition (50\%) (Bardon et al. 2014). This is a new insight in understanding plant-microorganism interactions and more specifically the ability of plant to shape microbial soil functioning by the release of secondary metabolites.

The positive effect of earthworms on plant growth is well documented in literature. In earthworm casts, mineral nitrogen can be released and made available for plants and bacteria (Nguyen Hong et al. 2011; Jouquet et al. 2008, 2011). Signal molecules such as auxine exert huge effect on plant growth. The auxine production by bacteria in nitrogen-rich casts could influence the root development towards earthworm casts and could lead to a more efficient nitrogen uptake by the plant and consequently a higher biomass production in a treatment with earthworms than in a control without earthworms. However, earthworms may also influence soil microbial properties and the transfer of microbes from soil to water. Two scales may be considered. At the soil aggregate scale, the genetic structure and the abundance of the bacterial and fungal communities were characterized using ARISA fingerprinting approaches and quantitative PCR, respectively. The analyses were performed directly on DNA extracted from earthworm cast aggregates and control soil aggregates non-recently influenced by earthworms (Jouquet et al. 2013). The cryptic properties of earthworm casts fragmented by the rain (i.e., earthworm casts are similar in appearance to the surrounding control soil aggregates) and the 
relevance of bacterial and fungal abundance and diversity as biological indicators of the origin of soil aggregates were confirmed (Jouquet et al. 2009). At the soil column scale, we showed that the presence of earthworms significantly reduced bacterial abundance in the soil organic layer after the incorporation of compost or vermicompost, but it did not influence bacterial and viral abundance in water, suggesting independent processes (Amossé et al. 2013).

During the gut transit in endogeic earthworms, microorganisms are awaked and their activities are stimulated by the small molecules contained in the mucus and by the meeting with fresh residues. Priming effect is defined as a stimulation of the soil organic matter mineralization by the amendment of fresh organic matter. This microbially mediated process is not completely understood, but it usually leads to the liberation of the nutrients ( $\mathrm{N}$ and $\mathrm{P}$ ) from the organic soil stock which becomes available to plant growth. During the incubation of a tropical feralsol amended by ${ }^{13} \mathrm{C}$-enriched straw residues, Pontoscolex corethrurus, a generalist tropical endogeic earthworm, could stimulate the priming effect by a factor of 2 (Bernard et al. 2012). A DNA-SIP approach showed that this stimulation was linked to specific bacterial phylogenetic groups belonging to the Bacteroidetes phylum (Cytophagaceae, Chitinophagaceae, and Sphingobacteriaceae). A second experiment demonstrated that the intensity of this process was dependent on the type of soiland the earthwormspecies andthatit mostly happens during the gut transit. Dichogaster saliens, a small-sized epiendogeic earthworm species, was able to generate an important priming effect in his gut, due to the stimulation of another family of the Bacteroidetes phylum, the Flavobacteriaceae. As this species is living at the root vicinity of Bracharia sp., it could mineralize nutrients and release it on contact with plant roots. Therefore, inoculation of such earthworm into agroecosystems should be considered in the future, as any other agroecological tool, in order to form a partnership with crops like it is already done with mycorrhiza.

The soil biological communities involved in litter decomposition (detritivores and heterotrophic microbial community) are shaped by nutritional constraints. In tropical forests with highly weathered and nutrient-impoverished soils, litter decomposition is thought to be particularly important for nutrient recycling. In order to understand how the availability of key resources control the decomposer communities and the processes they drive, plant litter quality and C, N, and P availability with fertilization were controlled in field and laboratory experiments. During a microcosm experiment with chemically contrasted litter species decomposing on the top of a common soil substrate, litter and soil microbial communities responded differently to $\mathrm{C}$ and nutrient availability. In the C-rich litter material with high $\mathrm{C} /$ nutrient ratios, the microbial community was mainly controlled by nutrient availability, with higher fungi/bacteria ratio for litter with high soluble N/P ratio (Fanin et al. 2013). In the C-poor soil, microbial C/nutrient ratios were relatively close to those of the soil organic matter, and the relative abundance of Gram-negative to Gram-positive bacteria was controlled by litter soluble C (Fanin et al. 2014). A field experiment at the experimental site of Paracou (French Guiana) showed that alleviating the $P$ limitation by $P$ fertilization resulted in a shift in the structure of the microbial community, with functional consequences (Fanin et al. 2012, 2015). A shift in the macroinvertebrate community was also observed with a higher number of detritivore and humivore species in Pfertilized plots. Moreover, distinct groups of macrofauna showed different C/N/P stoichiometries, but fertilization did not change group-specific biomass C/N/P ratios. 
Fungal saprotrophic communities play an essential role in plant organic matter degradation by producing hydrolytic enzymes active on lignocellulosic biomass. Open questions in this field regard the diversity of the species involved the major biochemical pathways implicated and how these are affected by environmental factors such as climate changes. The impact of reduced rainfall ( 33\%), simulating a predicted climate change in the Mediterranean area, on the diversity of expressed fungal genes encoding lignocellulolytic enzymes was evaluated. To access to the global diversity of these specific fungal transcripts, which represent a small proportion of the total soil mRNA pool ( $\sim 0.4 \%)$, sequence enrichments by PCR or gene capture are necessary. In parallel to the design of specific degenerate primers compatible with the Illumina MiSeq sequencing technology (Barbi et al. 2014), an original adaptationofthe solutionhybrid selection was developed for a fast and efficient recovery of functional fungal cDNAs synthesized from soil-extracted mRNA. This protocol was implemented on the glycoside hydrolase 11 (GH11) gene family encoding endoxylanases and tested on four different soil samples including the reduced rainfall forest soil (Bragalini et al. 2014). More than $90 \%$ of the captured cDNAs corresponded to fungal GH11 sequences and $70 \%$ were full length. Highthroughput sequencing highlighted hundreds of phylogenetically diverse fungal GH11 sequences and led to the identification of rare sequences present in the original sample. These innovative approaches offer the possibility of performing exhaustive functional exploration of fungal gene families within complex soil microbial communities and will be used to compare the transcript diversity within the control and reduced rainfall soils.

In attempt to understand the response of soil-to-water fluctuations, different scenarios of droughtwetting intensities were simulated in microcosms, and the dynamics of telluric microbial communities were followed to assess their stability in terms of diversity and function. A critical minimum moisture threshold below which microbial community stress was induced can be observed (Kaisermann et al. 2014). Below this threshold, the wetting of dry soils induced (i) large fluxes of $\mathrm{CO}_{2}$ (called the BBirch effect $^{\wedge}$ ), which could be finely predicted from the intensity and duration of drought and wetting, and (ii) erosion of bacterial diversity, leading to a structural instability in the following drought-wetting cycles. Despite an overall functional resilience, bacterial and fungal communities exhibited permanent modifications. Finally, the effects of drought-wetting events were also partially modulated by the soil physicochemical characteristics inherited from management practices (Kaisermann et al. 2013). These changes in microbial communities may be related to the size of soil pores, with more intense drying causing usually moist micropores to dry out. The stress of microbial populations less adapted to these disturbances could result in (i) higher population turnover and intense competition for new available ecological niches and (ii) the establishment of physiological mechanisms such as the synthesis of extracellular protections (C-rich glycocalyx). Upon wetting, this C would be immediately dissolved and mineralized. This is an alternative explanation for the increase in substrate availability and the $\mathrm{CO}_{2}$ flush that occurs after rewetting. Taken together, the integration of climate change drivers investigated in this work could improve the modeling of $C$ fluxes in soils undergoing drought-wetting cycles. It also raises the issue of the existence of a tipping point in the decline of diversity beyond which an erosion or cutoff of the functions and services provided by ecosystems could be induced (Lata and Kaisermann 2013). Beyond drought-wetting fluctuations in soils, multiple components of global change (increases 
i natmospheric $\mathrm{CO}_{2}$ concentration, temperature, nitrogen deposition, and precipitation) may affect soil microbial processes, such as nitrification and denitrification, two key steps of the $\mathrm{N}$ cycle, through changes in the soil environmental conditions but also through changes in the abundance and diversity of the associated microbial communities. Disturbances could also alter these microbial processes and communities, and a special interest would be the response of these microbial communities to the combined effects of gradual global environmental changes and fire disturbance in grassland ecosystems.

In continental ecosystems, the headwater streams remain poorly explored environments. Headwater streams are highly heterotrophic ecosystems wherein decomposers and higher trophiclevel consumers rely on terrestrial organic matter provided by surrounding vegetation as the main sources of carbon and nutrients. The ecological significance of autotrophic producers in these habitats (i.e., benthic algae) has yet to be determined. Producers can interact with decomposers in many ways. Producer-decomposer mutualism is thought to be a prominent interaction within ecosystems as producers provided dead organic matter to decomposers and the mineralization of detritus by decomposers leads to the release of inorganic nutrients necessary for producer growth. The coexistence of producers and decomposers is also ruled by asymmetric competition for inorganic nutrient acquisition and the possible dependence of decomposers upon labile carbon exudate released by producers. The detrital pool in streams is mainly made up of refractory organic matter (e.g., leaf litter and woody debris). Under this context, autochthonous producers should be competitively excluded by decomposers, which immobilize nutrients more efficiently (Danger et al. 2013a, b). This prediction is not supported by empirical evidence, which indicate that algae can coexist with fungal decomposers. Furthermore, leaf litter decay rate in two streams was found to be affected by experimental manipulation of light level, possibly through effects on autotrophic activity and positive producer-decomposer interactions (Lagrue et al. 2011). This hypothesis was verified using microbial microcosms wherein the presence of algae and nutrient availability were manipulated (Danger et al. $2013 a, b)$. Under low nutrient condition, such asin pristine headwater streams, algae was found to increase bacterial abundance by a factor $>4$ and to accelerate litter mass loss significantly. These results were attributed to a priming effect of labile organic carbon exudates from algae on decomposer activity. Evidence emerges from this research project that, even in heterotrophic streams where primary productivity is generally low, algae are still anintegral component of the microbial functional diversity.

In forested headwater streams, aquatic fungi such as aquatic hyphomycetes (a polyphyletic group of true fungi) are known to improve the palatability of detritus for detritivores, but their inherent quality for consumers is almost unknown. Aquatic hyphomycetes' elemental (nitrogen and phosphorus content) and biochemical (essential fatty acids) compositions were experimentally investigated concomitantly with environmental parameters to determine how microorganisms' quality could help their consumers to better resist to metallic contaminations. We hypothesized that higher quality resources would lead to higher energy storage by detritivores and thus reduce contaminant impacts. Results first revealed that aquatic hyphomycetes were able to synthesize high proportions of essential fatty acids (in particular, alpha linolenic acid, 18:3w3), these proportions being evenincreased under 
highphosphorus levels (Arce Funck et al. 2015). An original protocol aimed at manipulating leaf litter elemental quality using nutrient immobilizationcapabilitiesofaquatic hyphomyceteswas developed (Danger and Chauvet 2013). This approach showed for the first time that the detritivorous invertebrate, Gammarus fossarum, was susceptible to face large phosphorus limitations, reducing its growth and survival (Danger et al. 2013a, b). Elemental quality of detritus colonized by fungi was able to modulate the impact of ionic silver, a reemerging metallic contaminant, otherwise highly toxic for both fungi (Arce Funck et al. 2013a) and invertebrate detritivores (Arce Funck et al. 2013b).

In aquatic environments, the relationships between carbon nutrition and stress adaptations occur within complex communities of eukaryotic and prokaryotic microorganisms, relying on phototrophic, mixotrophic, or heterotrophic processes. These cellular processes directly affect nutrient fluxes, intraor interspecific interactions, and ecosystem functioning. Environmental metagenomic and metatranscriptomic approaches are ideally suited to analyze such nutrition-stress relationships in terms of cellular regulations (Couée and Bringel 2010) and in terms of cell-ecosystem integration (Vandenkoornhuyse et al. 2010). Such approaches were carried out on high-quality DNA and RNA purified from a spatiotemporal series of autumn water samples collected in a temperate freshwater reservoir situated in Brittany (northwestern France). Metagenomic and metatranscriptomic datasets were bioanalyzed to determine quantitative distributions of taxonomic and functional gene and transcript molecular markers. Molecular taxonomic analysis greatly extended the vision given by direct cell counts. Within compositional patterns that were typical of freshwater environments, it revealed the abundance of picocyanobacteria (Cyanobacteria), Rickettsiales (Alphaproteobacteria), and bacteria of the SAR11 family (LD12). Carbon and energy input through light-harvesting processes was abundantly represented by markers of oxygenic photosynthesis components, lightdriven proton pumps, and reaction centers of aerobic anoxygenic photosynthesis. A striking and unexpected feature of carbon-utilizing processes was the prevalence of molecular markers for xenobiotic metabolism and detoxification. These potential metabolic capacities covered a wide array of xenobiotic sources (polycyclic aromatic hydrocarbons, organochlorides, pesticides, solvents, plasticizers), thus raising environmental and evolutionary issues on the mechanisms underlying the conservation of xenobioticrelated defensomes in freshwater microbial communities. In the hypothesis of landscape-level diffuse pollution, it would be important to determine whether this situation reflects low-level, cryptic, or transient exposures to xenobiotics and whether low-level xenobiotic exposure induces subtle signaling disruption (Couée et al. 2013) of semiochemical sensing rather than wholesale biochemical and metabolic effects. However, in modern environments of phosphatogenesis such as meromictic lakes, an important efforthas to be deployed foridentifyingthe microbial molecular processes involved in the environmental phosphorus cycle, in particular by phosphorus storage/hydrolysis in relation to geochemical parameters, such as oxia-anoxia variations.

Studies could be focused on microbial phosphatases and kinases involved in the phosphorus storage as intracellular polyphosphates (Poly-P) or in the phosphorus release by hydrolysis of Poly-P or organic phosphate, which may be followed by reaction of phosphorus with calcium or metal ions and precipitation as phosphate mineral phases. 
In marine environments, few data are available on simultaneous estimates of heterotrophic bacterial production and respiration, and the source of variability of bacterial growth efficiency is hardly questioned, as it influences the fate of organic carbon channeled through bacteria (sink or link). The quantity and quality of organic matter and its stoichiometry C/N/P are key factors regulating the bacterial growth efficiency. Bacterial production and respiration, alkaline phosphatase activity (phos), and ectoaminopeptidase activity (prot) were monitored during 1-year survey at the long-term observatory SOLEMIO station (Marseille) (Céa et al. 2014). Optimal temperature and $Q_{10}$ varied seasonally. Bacterial growth efficiency did not necessarily decrease with increasing temperature. Irrespective of the in situ conditions (season, temperature), the bacterial assemblage showed a bacterial growth efficiency at the in situ temperature close to its temperature optima. The nature of interaction between temperature and resources was mostly synergistic. The relative changes in bacterial production, prot and phos activity following a shift in temperature, were potentially reflecting those of $\mathrm{C}, \mathrm{N}$, and $\mathrm{P}$ rates through heterotrophic bacteria. According to this scenario, $\mathrm{C} / \mathrm{N}$ and $\mathrm{C} / \mathrm{P}$ rate ratios increased after warming and decreased after cooling (Céa et al. 2015). Finally, temperature and phosphate availability were the main factors driving heterotrophic bacterial activity and thus play a fundamental role in carbon fluxes within the marine ecosystem.

In seagrass ecosystem of Mediterranean coastal lagoon, the organic enrichment follows generally heat wave. The general working hypothesis was that after heat wave, the changes in biodiversity and carbon cycle in the seagrass food web depended upon the level of enrichment. The response to extreme temperatures (increase up to $5-6{ }^{\circ} \mathrm{C}$ for several consecutive days) and nutrient supply of the benthic food web, from bacteria to macro-organisms, including the role of the symbiosis between macrofauna and sulfur-oxidizing bacteria was recently studied in an explorative field survey (Rossi et al. 2013). The observation of the macrofauna distribution in the eelgrass Nanozostera noltii at two selected beaches in the lagoon of Thau showed differences in community composition and structure between $N$. noltii patches and the bare sediment and differences between the edges and the centers of the eelgrass patches. The bacterial composition of the bivalve Loripes lacteus can host sulfuroxidizing bacteria and the relationships between bacterial community and the feeding behavior of the host, using stable isotopes $\left({ }^{13} \mathrm{C}\right.$-bicarbonate) to follow the carbon cycling in the benthos. These experiments reveal that $N$. noltii sustains a highly diverse community and high abundance of the symbiotic species L. lacteus. The bacterial population on the gills of this species is highly variable. The macrofauna diversity and the eelgrass biomass have partly changed responding to the heat wave.

Mediterranean rainfall events are short and intense, leading to flash floods, particularly in autumn. Flooding is caused by large volumes of river water transporting river and terrestrial material, including organisms, nutrients, mineral and organic matter, as well as pollution. Little is known about the direct effect offlash floods on coastal marine waters, mainly because they are episodic and unpredictable. Some reports suggest that the positive or negative effect of the flood event is strongly dependent on the functional groups (primary producers, remineralizers, and predators) present in the marine waters. The short-term impact of a Mediterranean autumnal flash flood on the abundance, biomass, diversity, and production of the coastal microbial food web was studied along a fixed salinity gradient in the marine Thau Lagoon. The direct consequences of river discharges on the coastal food web, excluding 
hydrodynamic effects, were tested using an experimental in situ mesocosm approach with the addition of different volumes of river water into the mesocosms containing Thau Lagoon water. The substantial loading of inorganic matter in the river encouraged the development of marine diatoms (Pecqueur et al. 2011) despite the significant increase in some heavy metals such as $\mathrm{Zn}$ (from 6 to $>30 \mu \mathrm{g} \mathrm{L}^{-1}$ ) in floodimpacted lagoon waters. However, the large inputs of organic matter from the rivers did not benefit marine heterotrophic bacteria, which appeared to be partly dependent on the increased carbon primary production and only contributed moderately (on average $40 \%$ ) to the total $\mathrm{NH}_{4}$ and $\mathrm{NO}_{3}$ incorporation rates (Trottet et al. 2011). The river microbial components discharged into the marine lagoon did not contribute to the overall increase in lagoon microbial production probably because they were affected by the saline water (Pecqueur et al. 2011). The lagoon microbial community that was produced locally during the flood was transferred rapidly, within days, to the highertrophic level (Fouillandet al. 2012), in agreement with the experimental mesocosm observations.

Another multidisciplinary study exemplified the impact on the near-shore marine ecosystem of flash flooding events in a small Mediterranean catchment covered by vineyard (60\%) and forest (30\%) upstream and urbanized downstream (10\%). Fluxes of nitrogen, phosphorus, copper, and microbes ofenteric origin drained to the sea during flash floodingevents in 2009and 2010fromthe Baillaury River watershed ( $18 \mathrm{~km}^{2}$, Banyuls-sur-Mer, France) were assessed. The fate of these inputs at sea and their impact on phytoplankton and alkaline phosphatase dynamics was monitored in Banyuls Bay combining Eulerian stations with a Lagrangian survey of the low saline plume. Nitrogen was mainly delivered in nitrates form, while phosphorus delivery was distributed in dissolved and particulate, organic and inorganic forms. At sea, while nitrates were diluted without significant consumption, the dynamics of other nitrogen and phosphorus compounds suggest consumption or production occurred during the 2 days in which dilution of riverine inputs was detectable. During low saline period, alkaline phosphatase decreased, drastically for the more than $2-\mu \mathrm{m}$ fraction. The pre-existing diatom bloom was cleared 5 days after the flood peak, but phytoplanktonic populations started to bloom again on the sixth day, to yield higher chorophyll-a concentrations than pre-flooding event. Copper transfer during flash flooding events was mainly associated to non-residual fractions of particulate matter ( $>25 \%)$, dominantly adsorbed onto iron oxide fractions. A small fraction of Cu was associated with organic matter (5 to 10 \%). The anthropogenic contribution was estimated between 50 and 85 \% (El Azzi et al. 2013).

To understand, characterize, and predict changes in marine ecosystem biogeochemical cycles in relation to climate change, it is necessary to better understand the dynamics of organic matter. In this context, the induction of photooxidative processes in bacteria attached to phytodetritus and its implications in the transfer of organic material has been studied. The intensive effect of singlet oxygen on unsaturated fatty acids of bacteria associated to lightened phytodetritus has been observed, while lipidic components of isolated bacteria were unaffected. The magnitude of this oxidation appeared to be well correlated with the amount of chlorophyll photodegraded in the algae (Petit et al. 2013). Moreover, due to the short lifetime of singlet oxygen in polar media, constitutive silica frustules of diatoms limited the photochemical alteration of bacteria attached to phytodetritus (Petit et al. 2015a). In contrast, calcium carbonate coccoliths of haptophytes, which are lost during algal senescence, did 
not affect significantly this process. At the late stationary phase, more than $90 \%$ of the attached bacteria were dead, while half of the free bacteria were still alive. At this time, the bacterial community associated to the algae appeared to be very simplified and dominated by pigmented species (i.e., possessing photoprotective systems favoring the resistance to the oxidative stress) (Petit et al. 2015b).

Iron is the most abundant elements on Earth and the most frequently used transition metal in biosphere. Through the capacity to use Fe(II) as an electron donor, neutrophilic iron-oxidizing microorganisms play an important role in iron redox cycling. Iron oxidizers are flourishing at circumneutral $\mathrm{pH}$ forming microbial mats in streams. Questions about the local and spatial diversity, the microbial mat functioning, and the understanding of biotic interactions were addressed using a new in-depth metatranscriptomic and metagenomic approaches. Strikingly, the mat microorganism diversity was dominated by only six phyla corresponding mainly to iron-immobilizing bacteria and surprisingly methanothrophs. Richness and diversity estimates based on the analyses of 16S rRNA gene transcripts showed a significantly lower microbial diversity at the surface than in deeper regions of the microbial mat revealing vertical stratification of the community and ecological processes at centimeter scale. This indicates a strong organization of the microbial mat, which was further confirmed by the analyses of (i) rRNA transcripts, (ii) transcripts encoding the particulate methane monooxygenase subunits (pmocAB), and (iii) genome recruitments. These analyses clearly support that methanothrophic microorganisms are more active at the depth conversely to ironimmobilizing microorganisms, which are more active at the surface. Furthermore, autotrophic iron oxidizers showed co-variation with relative higher dissolved inorganic carbon concentrations and redox potential pointing to the linkage of microbial activities to environmental factors. Together, this provides strong evidence of a vertical partitioning of coexisting microbial populations performing essentially iron oxidation and aerobic oxidation of methane. The association among methanotrophs and ironimmobilizing microorganisms is arguably an important form of symbiosis involved in iron cycling, which contributes to alleviate methane emission (Quaiser et al. 2014).

What happens in the air? Within the last decades, cloud droplets were demonstrated to host diverse and active microbial communities. The metabolic processes involved may impact atmospheric chemical reactivity, as shown on natural cloud water samples incubated under laboratory conditions: utilization of dissolved organic and nitrogenous compounds and interactions with free radicals and metals, notably. Moreover, some microorganisms could have microphysical influence on clouds, for example by expressing ice nucleation active proteins. In turn, the drastic conditions encountered by cells in clouds likely influence their metabolic activity and survival. Metagenomics and metatranscriptomic analyses appeared as promising tools for discovering which particular microbial groups are metabolically active in cloud water, which chemical compounds are targeted, and how microbial cells maintain in such hostile environments. New generation sequencing analyses of ribosomal amplicons confirmed that clouds harbor very diverse microbial communities composed of Eukaryotes, Bacteria, Archaea, and viruses. Community's composition greatly varied from a cloud to another at our sampling site (the Puy de Dôme summit, 1,465 m a.s.l.), but Proteobacteria largely dominated in all cases (they invariably represented about 2/3 of the OTUs identified). Many other groups were detected, like Firmicutes (spore-forming species), Actinobacteria, and Cyanobacteria 
(photosynthetic species) for example. Preliminary results of metagenome and metatranscriptome sequencing after multiple displacement amplifications revealed the presence of numerous genes related to cell division, stress response, metabolism of aromatic compounds and carbohydrates, and methylotrophy, notably. These give hints for elucidating microbial's functioning in clouds. The compilation of diversity, metagenome, and metatranscriptome data gathered in this work will provide the first extensive pictures of the microbial life existing in clouds.

\section{Microbe-microbe and host-microbe interactions}

A large variety of microbe-microbe and host-microbe interactions were explored in continental, coastal, and marine environments.

Exchange of chemical signals and nutrients plays a key role in the dynamics of the plant-microbiota interactions. Some rhizospheric bacteria induce $\mathrm{N}$-fixing symbiotic nodules on different plant species. The actinobacterium Frankia and a large group of symbiotic dicotyledonous plants together represent about $15 \%$ ofthe nitrogenfixed globally and play a key role in the establishment of ecological succession in disturbed habitats such as glacial moraines, lava fields, burned forest areas, or mine spoils. The transcriptome of both partners in the symbiotic interaction was analyzed. This information should lead to the identification of molecular markers for the purification of factors involved in the signaling dialogue between plant and bacteria. On the Frankia alni side, the main result is the absence of symbiotic islands containing genes overexpressed in symbiosis (Alloisio et al. 2010). On the side of Alnus and Casuarina host plants, the main result is the existence of genes known in legumes to be involved in the signalling cascade, necessary for the establishment of symbiosis (Hocher et al. 2011).

Bacterial composition of the phyllosphere, aerial parts of plants, is influenced by a wide range of plant-related factors such as nutrient availability, metabolites, and antimicrobial compounds produced by plants. In Arabidopsis thaliana, release of chloromethane, a toxic gas involved in atmospheric ozone destruction, depends on gene HOL1 encoding a methyltransferase catalyzing the transfer of the chloride ion to Sadenosylmethionine. The bacterial functional and structural diversity of the phyllosphere of three $A$. thaliana variants expressing the HOL1 methyltransferase gene at different levels was explored using 454-pyrosequencing of PCR amplicons of 16S rRNA gene and of the cmuA gene for chloromethane dehalogenase (Farhan UI Haque et al. 2013). Analysis of the 16S rRNA gene amplicons showed that Methylobacterium accounted for more than $80 \%$ of the recovered taxonomic diversity at the genus level irrespective of the $A$. thaliana variant. Significant differences were only observed for Sphingomonas. However, differences in the phyllosphere bacterial populations between the three variants were detected when the chloromethane dehalogenase gene $c m u A$ was considered. Particularly, the $A$. thaliana variant, overexpressing the chloromethane-producing HOL1 methyltransferase gene, presented the broadest diversity of $c m u A$ sequences.

Sphagnum-dominated peatlands develop from fen to bog in a succession from nutrient-rich minerotrophic fen to nutrientpoor ombrotrophic bog. Viral abundance and diversity in these ecosystems remain uncharacterized: precisely a comparison of the seasonal abundance and diversity 
of virus and bacteria in fen and bog; an examination of which environmental factors drive the distribution of these communities; and an estimation of the ecological importance of virus in the ecosystem functioning. These investigations will give a novel insight into viral and bacterial dynamics within Sphagnum microbiota.

In plant microbiota, numerous bacteria are able to communicate and synchronize their behavior using quorum-sensing and signals of the $N$-acyl homoserine lactone (AHL) class. A study evaluated the consequences of the cultivation of AHLdegrading plants on rhizospheric microbiota using wild-type Nicotiana tabacum plants and genetically engineered plants expressing the attM gene from Agrobacterium. AttM is a lactonase that degrades QS signals. Cell densities of total cultivable bacteria and those of selected populations (pseudomonads, agrobacteria) isolated from plant rhizospheres and rhizoplanes were enumerated on semi-selective media and found comparable irrespective of the genotype of the plants. Similarly, cell densities of members of the bacterial communities relying upon $\mathrm{AHL}$ to communicate, or naturally degrading $\mathrm{AHL}$ signals, were identical and independent of plant genotypes. Bacterial populations isolated from the two plant genotypes were also analyzed irrespectively of their cultivability status. Denaturing gradient gel electrophoresis analyses that targeted the 16S rRNA gene did not reveal any significant differences within these populations. All these data indicate that bacterial population changes that could have resulted from the genetic modification of the plants are non-existent or very limited, as no changes linked to the plant genotype were observed (D’Angelo-Picard et al. 2011).

Several plant pathogens, such as Pectobacterium atrosepticum, use a quorum-sensing communication system based on signals of the $\mathrm{AHL}$ class to regulate the production of virulence factors. Degradation of the quorumsensing AHL signals by biocontrol bacteria has been proposed as a novel strategy to protect crops, such as potato plants, against the worldwide pathogen Pectobacterium. The dynamics of the total bacterial community and that of the native and introduced AHL-degrading Rhodococcus erythropolis (strain R138) populations were analyzed under treatments by two growth-biostimulating agents: gamma-heptalactone (GHL) and gamma-caprolactone (GCL). The higher densities of AHL-degrading $R$. erythropolis population in rhizosphere were observed when GHL or GCL treatment and AHL-degrading R. erythropolis R138 were associated. Under this condition, the introduced R. erythropolis displaced the native $R$. erythropolis population. Chemical analyses revealed that GHL and GCL and their by-products rapidly disappeared from the rhizosphere and did not accumulate in plant tissues. This integrative study highlighted the biostimulation strategy as a potent innovative approach to improve root colonization by beneficial AHL-degrading bacteria (Cirou et al. 2012). The GCL amendment also stimulated the growth of the members of the native AHLdegrading bacterial community in a plant hydroponic system for the mass production of Solanum tuberosum (Cirou et al. 2011). Finally, functional metagenomics allowed the discovery of a novel bacterial AHLdegrading enzyme, QsdB, in a rhizosphere that was treated with GCL. Among the 29,760 fosmids of the metagenomic library, a single one was detected that conferred NAHL degradation upon Escherichia coli. The purified QsdB enzyme exhibited an amidase activity. QsdB was the first amidase signature (AS) family member that exhibited a NAHLase activity (Tannières et al. 2013). 
Physiological, metabolic, and molecular interactions between host and microorganisms (mainly pathogens) are now well known in terrestrial plants. Endophytic fungi, microorganisms inhabiting plant organs without causing apparent damage on the host, are able to protect the host-plant against biotic and abiotic stress through the production of fungal molecules. However, in macroalgae, investigationsare still in their infancy, and the study of the diversity and the role of endophytic fungi associated with seaweed is still largely unexplored. Multidisciplinary approaches could help to determine whether endophytic fungi are likely to protect host-algae against particularly the lethal abiotic stress. Especially, the question arose about potential of the metabolome (primary and secondary metabolites) of fungal strains isolated from Laminaria digitata to protect against different stresses suffered by the host-algae (salinity, brightness) particularly in a context of global change (temperature). This investigation is of a particular interest because L. digitata is widely exploited for its alginate content.

Aside from plant hosts, two studies revealed the dynamics of microbiota in insects. Microsporidia are unicellular eukaryotes and invasive intracellular parasites infecting a wide range of animals, including most of the insect taxa. In the Western honeybee Apis mellifera, the emergent microsporidian Nosema ceranae presents a highprevalencein colonies worldwide and is often considered as an important factor contributing to the honeybee population decline. However, the presence of the parasite is not systematically associated with pathology, suggesting variations in its virulence. As such variation could reflect the existence of parasite variants, the nucleotide diversity of $N$. ceranae isolates has been assessedusing a multilocus approach on ten genetic markers, including the small subunit ribosomal RNA encoding gene. While high nucleotide diversity and allele content were observed for all ten genes, this diversity was mainly present within parasite populations isolated from single honeybee individuals (Roudel et al. 2013). In contrast, the absence of isolate differentiation precluded any taxa discrimination, suggesting that geographically distant honeybees are infected by a similar parasite population. These results are in agreement with the hypothesis of a recent host jump of $N$. ceranae from the Asian honeybee (Apis cerana) to the Western honeybee. They also suggest that the parasite population is in expansion and maybe not isolated from its original population in $A$. cerana.

Originating from Southeast Asia, Aedes albopictus is considered as one of the most invasive species worldwide. Insectassociated microbiota are recognized as playing a significant role in host biology; hence, they can be hypothesized to help understand the puzzle the driving forces of Ae. albopictus adaptation and subsequent invasiveness. In order to test this hypothesis, a method allowing reaching a complete picture of the nature and abundance of mosquito-associated bacterial microbiota is needed. A pilot experiment was undertaken to test different aspects of amplicon preparation and sequencing depth using high-throughput pyrosequencing on V5-V6 region of the 16S rRNA gene (Minard et al. 2014). This approach was performed on whole body of field-caught mosquito populations from Madagascar. Surprisingly, the results showed that bacterial microbiota was largely dominated by the endosymbiotic bacterium Wolbachia pipientis (96 to $99 \%$ of the whole bacterial content). Apart from Wolbachia, a total of 31 bacterial taxa were identified at the genus level from less than $1 \%$ of all sequences. Diversity index values were low and probably underestimated the true diversity due to the high abundance of Wolbachia sequences. The results show the limits of the high- 
throughput sequencing approach when there is a dominant endosymbiotic species. Another strategy is currently being studied considering targeted analysis on the mosquito gut, an organ known to harbor a lesser amount of this Wolbachia.

Dynamics of pathogens are dramatic concerns in oysterand mussel populations. An approach was developed to monitor in situ the microbiota, the health of oysters, and environmental parameters during two mortality events affecting shellfish farms in Thau lagoon (2010 and 2011, Hérault, France). This monitoring (Schmitt et al. 2014) has highlighted at the time of the onset of mortality very large increases in the microbiota with a drop in the abundance of bacteria of the Vibrio genus with concomitant detection of pathogens (herpes virus OsHV1 and Vibrio splendidus). Changes were not only quantitative but also qualitative: we observed an important loss of diversity ofthe dominantbacterial communities withinoysters during mortality, as revealed by temporal temperature gel electrophoresis. Regarding oysters, this study has characterized an effective immune response (versus a non effective response) of oysters faced with mortality (gene expression analysis of one hundred genes) and a health status favorable to survival (Schmitt et al. 2014). Altogether, the data show a high variability of the oyster responses and of the associated microbiota according to the capacity of oyster to survive and highlight variables of interest (oyster and microbiota) to go inside the interactions between oysters and microbiota in the context of oyster mortalities.

When exposed to $A$. catenella, a paralytic shellfish toxin (PST) producer, an apoptotic process occurs in the Pacific oyster, Crassostrea gigas. In a recent work (Medhioub et al. 2013), oyster individuals were experimentally exposed during $48 \mathrm{~h}$ to the PST producer dinoflagellate and compared to the non-toxic A. tamarense. Results show the up-regulation of genes involved in the mitochondrial pathway of apoptosis followed by the overexpression of two executor caspase genes. In addition, a significant increase of the number of hemocytes (immune cells) in apoptosis was observed after exposure. In the digestive gland, the tested genes Bax, BI.1, and cytochrome P450 (CYP1A) were significantly upregulated in the digestive gland of oyster exposed $48 \mathrm{~h}$ to $A$. catenella. Beside this, a significant increase in ROS production was observed, as well as a decrease in caspase-3/7 activity and percentage of apoptotic cells. Taken together, these results suggest a feedback mechanism occurs in the digestive gland where BI.1 could play a key role to prevent the induction of apoptosis by PSTs. Moreover, the expression of CYP1A, Bax, and BI.1 was found to be significantly correlated to the occurrence of natural toxic event suggesting that the expression of these genes togethercould be used as a biomarker to assess the biological responses of oysters to stress caused by PSTs. Apoptosis has been recognized to be essential defense mechanisms in oysters against invasion of pathogens. Studies are now in progress to better understand how the control of this stress could increase the susceptibility of oysters to environmental pressures or diseases.

Human waterborne protozoa had been detected in various water courses (Palos-Ladeiro et al. 2013). Actually, protozoa detection was based on large water filtration. Zebra mussel, Dreissena polymorpha, a filter feeder already used to emphasize water course chemical contamination, represent an interest in pathogen detection and quantification. Some authors evaluated the optimization of a simple and unique process to concentrate different pathogens from mussel tissues using trypsin digestion; they also investigated lysis procedures of Toxoplasma gondii oocysts and quantification by real-time qPCR. 
Additional experiments confirmed (in the cases of Cryptosporidium parvum and Giardia duodenalis) or showed for the first time (in the case of $T$. gondii) a pathogen bioaccumulation by mussel in proportion to the ambient contamination (Palos-Ladeiro et al. 2014). Concerning T. gondii, DNA was detected in all organs, but higher concentrations were found in hemolymph and mantle tissues (Palos-Ladeiro et al. 2015). These data underscore zebra mussel capacity to reveal the ambient biological contamination and, thus, mussels could be a new effective tool in sanitary biomonitoring of water courses.

Vibrios cause major losses in shellfish farming and are associated to recurrent mortalities of oysters. However, to date, the role of plankton species in the transmission of pathogenic vibrios in oyster $C$. gigas is largely unknown. It would be of interest to identify in situ and in vitro the interactions of pathogenic vibrios with local species of plankton from different sites of Thau Lagoon, an important region for shellfish farming in south of France.

Aside from the direct interactions between pathogens and oysters and mussels, other complex interactions may involve microbes and a large diversity of plankton species. Some groups of the gelatinous plankton can proliferate, hence can modify the functioning of the coastal marine ecosystems. In this context, a study investigated the modifications of bacterial communities (structural and functional traits) in the presence of two groups of the Mediterranean gelatinous plankton, the jellyfish Aurelia aurita and the ctenophore Mnemiopsis leidyi (Blanchet et al. 2015). Two types of approaches were carried out: sampling campaigns with stations located in Thau and Bages-Sigean lagoons and experimental approach with enclosures in order to study the dynamics of the bacterial communities with and without the presence of gelatinous plankton. These two types of approaches were used to investigate (i) the abundance of bacteria and their diversity, (ii) the effect of the exudates from the gelatinous plankton on the bacterial metabolism, and (iii) the fate of the organic matter released from the gelatinous plankton with a focus on the processes of its biological breakdown by bacteria. The experiments showed that the exudates can promote a positive effect in term of bacterial and viral abundances. They also revealed the high bioavailability of the jellyfish material leading to (i) a rapid mineralization of the DOC and dissolved organic nitrogen from the jellyfish and (ii) the accumulation of high concentrations of ammonium and orthophosphate in the water column. Resilience of the bacterial community after the addition of DOM from the jellyfish was higher for metabolic functions than diversity, suggesting that jellyfish blooms can induce durable changes in the bacterial community structure in coastal lagoons.

Some species of phytoplankton, microalgal species of the genus Pseudo-nitzschia, are highly toxic, because of the production of domoic acid, an amnesic toxin, which can be lethal to humans but also birds and marine mammals. The production of domoic acid is variable in the Pseudo-nitzschia strains and sensitive to their surrounding environment (reviewed Lelong et al. 2012a). Lelong et al. (2011) evaluated the effect of different biotic but also abiotic factors on production of domoic acid, as well as on the physiology of phytoplankton cells. Results from this work highlight that the presence of bacteria is essential for domoic acid production and that different bacterial communities induce different physiological responses (Lelong et al. 2014). Remarkably, domoic acid promotes bacterial growth. However, although domoic acid is a chelator of copper and iron, it does not protect bacteria or microalgae against high doses of copper and is not produced by a non-toxic species under iron and/or 
copper limitations (Lelong et al. 2013). Domoic acid seems only produced in case of competition with bacteria, and its production is not affected by high doses of copper or the co-occurrence of another diatom (Lelong et al. 2012b). These observations suggest that the phytoplankton-bacteria interaction could induce the production of domoic acid. The questions remain as to how some bacterial communitiesact on Pseudo-nitzschia cells to induce domoic acid production and/or by which mechanisms do Pseudo-nitzschia cells respond to these bacterial communities (Lelong et al. 2014).

Other interactions deserve to be explored, such as the microbe-algae interactions and microbemicrobe interactions in biofilms. In marine environment, microbial biofilms cover most of the solid surfaces. Biofilms are multi-cellular systems in which many interactions occur, but competitions and complex cooperation are still poorly understood. It remains to understand the processes by which marine microbial actors interact within biofilms and, in the long run, to understand their influence on their environment. Positive or negative interactions between microorganisms could be compared in different biofilm such an intertidal temperate mudflat biofilm of French Atlantic coast and a corrosion product-microorganism composite biofilm formed on carbon steel structures immersed in a French Atlantic harbor. This knowledge is essential for a better understanding of the ecological role of microphytobenthic biofilm for the good biogeochemical functioning of coastal mudflats. This work is also essential for the elucidation of the role of bacteria in the accelerated localized corrosion of metallic structures in marine environment, which can cause considerable damages.

\section{Pollutants and microbes}

Environmental damages by pollutants depend on their toxicity, bioavailability, stability, diffusion, and abundance. Human activities (medicine, urbanization, transport, industry, agriculture) produce numerous pollutants of which the diversity varies according to technological processes. At the beginning of the twenty-first century, nanoparticles emerge as novel pollutants.

Titanium dioxide nanoparticles $\left(\mathrm{TiO}_{2}-\mathrm{NPs}\right)$, widely used as nanomaterials, are chronically released into the environment. Information regarding the impact of a realistic concentration of nanoparticles on soil organisms is currently limited, and the importance of soil characteristics is often neglected in ecological risk assessment. There are only few data on transport of nanoparticles through soils, and hence characterization of nanoparticles behavior and associated potential bioavailability and toxicity remain to be elucidated (Simonin and Richaume 2015c). For this, the behavior/mobility of $\mathrm{TiO}_{2}-\mathrm{NPs}$ was characterized in a column experiment. Then, the response of soil microorganisms and potential consequences for ecosystem functioning were assessed in a microcosm experiment using six contrasted soils. The contamination of soils with 1 and $500 \mathrm{mg} \mathrm{TiO} 2-\mathrm{NPs} / \mathrm{kg}$ (realistic and high concentration, respectively) revealed that in most soils, $\mathrm{TiO}_{2}-\mathrm{NPs}$ had no impact on microbial communities. Microbial activities and abundances were significantly lowered, even with the realistic NP concentration only in the silty-clay soil exhibiting a high organic matter content (Simonin et al. 2015). In this soil, $\mathrm{TiO}_{2}$-NPs were more strongly retained in the soil matrix than coarse-textured soils, 
and the nitrification appeared to be more affected by $\mathrm{TiO}_{2}$-NPs than denitrification. These results question the overall impact of these pollutants on the ecosystem functioning.

During the twentieth century, the intensive coal and steel industries contributed to the chronic pollution of soils. Their dismantling left large areas of wasteland soils highly contaminated by recalcitrant organic compounds such as polycyclic aromatic hydrocarbons (PAH). The properties of these soils need to be studied to better understand their functioning and evaluate their potential for bioremediation. Firstly, the microbial communities inhabiting an aged PAH-contaminated soil was characterized, and the PAH pollution over time was monitored. Long-term insitu experimental plots wereusedto monitor both bacterial and fungal community structures during natural and plant-assisted attenuation (Cébron et al. 2009; Thion et al. 2012). Plants increased the microbial densities and the diversity levels and favored the $\mathrm{PAH}$-degrading bacterial population belonging to the Actinobacteria. However, during the same period, the PAH pollution level decreased slowly in both planted and unplanted situations, and this was mainly explained by low PAH bioavailability (<1 \%) (Cébron et al. 2013). Secondly, in order to understand the biological functioning of this aged PAH-contaminated soil, organisms from various trophic levels (bacteria, fungi, protozoa, nematodes, and micro-arthropods) were studied, and microbial enzymatic activities and soil respiration were evaluated (Cébron et al. 2011). The results showed that plants had a positive influence on the development of all organisms of the whole trophic chain. The last objective was to evaluate the impact of various remediation strategies on the microbial community. Bacterial and fungal community structure modifications occurring consequently to the amendment with clay minerals, wood sawdust, and organic matter from plant roots extracts were highlighted (Cébron et al. 2015).

Treatment and recycling of industrial (high contamination) and municipal (low contamination) sludge are important environmental issues. Different aspects have been addressed in order to investigate (1) the relationship between microbial diversity and pollutant degradation and (2) the effect of oxic/anoxic oscillations on bacterial communities and their ability to degrade hydrocarbon compounds and reduce their related toxicity. Originality and innovative nature of this work were based in part on the comparative study (vertical and horizontal) of the diversity and the role of microorganisms in hydrocarbon degradation, combining cultural and molecular approaches, and on multidisciplinary microbiology/chemistry/toxicology approaches to study the dynamics of pollutants and microbial populations. Important ecosystem functions, such as xenobiotic degradation, were strongly affected by the loss of diversity (Cravo-Laureau et al. 2011; Hernandez-Raquet et al. 2013). In addition, the results suggested that functional microbial diversity is essential for better functioning of microbial ecosystems, particularly for pollutant removal. Furthermore, it has been shown that environmental fluctuations such as oxic/anoxic oscillations affect the bacterial community structure (Cravo-Laureau et al. 2011; Vitte et al. 2011, 2013). These studies have shown a first disturbance of community structure after oxygen addition, followed by a succession of bacterial populations over time correlated to a successive use of the substrates (Vitte et al. 2011). A toxicity decrease was observed particularly in oxic conditions, probably due to a better elimination of metabolites from PAH degradation and other toxic compounds in the sludge (Vitte et al. 2013). Thus, the study highlighted 
the importance of using biological, chemical, and toxicological complementary approaches to evaluate bioremediation strategies.

In the acid mine drainages, bacteria of the genus Thiomonas play a role in the transformation of metals or metalloids such as arsenic (Kruger et al. 2013). Because of their activity, Thiomonas strains are involved in natural remediation observed in some acid mine drainages. Proteomic tools were developed to quantify the expression of target proteins required for in situ functioning of Thiomonas strains, in particular to analyze the expression pattern of the arsenite oxidase. This approach identifies peptide signatures which are specific to each protein (Arsene-Ploetze et al. 2012, 2015). The assay was designed to allow discriminating Thiomonas strains and differentiate orthologous proteins from each strain thanks to a refined choice of unique and discriminant peptides. Once optimized, the method was applied to in situ studies, in samples collected in an AMD-impacted creek from three different places along the creek and two times over the year (winter and summer). In this way, the expression of the arsenite oxidaseof different Thiomonas bacteria was observed. Moreover, this method also permitted to determine which Thiomonas bacteria are active. In acid mine drainages, the structure of the microbial community was also investigated using metagenomics. A new genus (Candidatus Fodinabacter communificans) and Euglena mutabilis, a photosynthetic protist, represent key members of the microbial community in acid mine drainages at Carnoulès (France). An important challenge is identification and modeling of the metabolic fluxes between these two species and the surrounding microbial community.

Arsenic contamination of water supply by toxic forms of arsenite and arsenate has been frequently reported in various parts of the world, including France. The genes and proteins which are possibly involved in arsenic metabolism were investigated within a microbial community in a former mine. The characterization of physical-chemical parameters revealed that the mine of Gabe-Gottes (Alsace, France) had a concentration of arsenic compounds of $320 \mathrm{ppm}$, higher than the mean concentration of the geochemical Alsatian background (10-50 ppm). By the analysis of the 16S RNAencoding gene, 250 isolates were identified among the strains able to grow on $7 \mathrm{mM}$ arsenite. In parallel, a functional study targeting arsenic metabolism was undertaken. Genes homologous to aioAB known to encode an enzyme involved in arsenite detoxification were amplified by PCR with degenerate primers and sequenced. A thorough study of their phylogeny highlighted several phyla signatures and the possible acquisition of some aio genes by horizontal transfer (HeinrichSalmeron et al. 2011). Finally, the structure and the functioning of the microbial community were further studied by metaproteomics. This approach required an optimization of both protein extraction protocol and identification procedure by LC-MS/MS and was shown to be a valuable taxonomic tool. In addition, proteins identified, mostly involved in general metabolism and stress response, also revealed a microbial community particularly suited to thrive in such an arsenic-rich environment (Halter et al. 2011).

The restoration of the contaminated soil of ancient and active mines is a worldwide issue. In South Africa, three coal mines, near the town of Johannesburg (South Africa), were sampled. The collected bacteria were characterized and could be used as biological agents for promoting the precipitation of toxic elements in solution. In Morocco, mining wastes of the district of Oujda can be considered like extreme environments because ofthe presenceofhigh concentration of $\mathrm{As}, \mathrm{Pb}$, or $\mathrm{Zn}$. Despite semi-arid 
climate and high content of pollutants, a tolerant flora is capable to grow. These plants and associated microorganisms represent a resource for the establishment of a vegetative cover that would limit the erosion by wind and water. An integrative study of the plants and microbiota could help in accelerating the process of rehabilitation of contaminated areas.

Lagoons and coastal waters are contaminated by a large number of chemicals discharged directly or carried by rivers and runoff water that drain catchment areas in which agricultural activities take place. The major pesticides detected in the coastal lagoons (Thau and Bages, France) were diuron (0.014$0.13 \mu \mathrm{g} / \mathrm{L})$, glyphosate $(0.032-0.085 \mu \mathrm{g} / \mathrm{L})$ and its by-product aminomethylphosphonic acid (AMPA) (0.041-0.21 $\mu \mathrm{g} / \mathrm{L})$, and hydroxyterbutylazine $(0.012-0.059 \mu \mathrm{g} / \mathrm{L})$. When a flood event occurred, high concentrations of particulate contaminants were measured during the rising period of the flood; concentrations decreased then after the peak flow. Since dilution and self-purifying processes are not able to take place in intermittent rivers during dry periods, permanent anthropogenic inputs are accumulated and transformed in riverbeds. Glyphosate was more biodegradable than diuron in lagoon and coastal waters, when diuron was more photodegradable than glyphosate in these environments. A new luminescent biosensor using the marine green alga Ostreococcus tauri for toxicity testing in the environment was developed (Sanchez-Ferandin et al. 2013). Diuron and Irgarol 1051, two antifouling biocides commonly encountered in coastal waters, were chosen to test this new biosensor along with two degradation products of diuron. The advantages of this biosensor over cell growth inhibition testing are the sensitivity and the possibility to automate the analysis to provide a highthroughput laboratory approach for short-term toxicity tests. The ability to genetically transform and culture recombinant $\boldsymbol{O}$. tauri gives it huge potential for screening many other toxic compounds. A biosensor based on monitoring membrane esterase activity and the photosynthetic activity in immobilized unicellular marine algae was also proposed (Durrieu et al. 2011). The signal emitted by the sensor was disturbed by the presence of two herbicides (diuron and glyphosate), as well as several of their photodegradation products (DCPU, DCPMU, AMPA). The system proposed appears useful as rapid and costeffective analytical tools for continuous control of coastal waters.

Natural phototrophic biofilms are recommended to investigate the toxicity of pesticides. But the mechanisms that mediate the community structure, its dynamic, and the biological succession processes during phototrophic biofilm development can interfere with the pesticide-related effects. The hypothesis whether the communities produced in natural environments with different anthropic pressures, or in bioreactor with different maturation levels, can exhibit different responses to a noninhibitor photosynthesis herbicide co- or post-exposure (alachlor at 1 to $30 \mu \mathrm{g} \mathrm{L}^{-1}$ ) was tested. Mature phototrophic biofilms (4 weeks of age) exhibiting different natural growth environments, rivers in agricultural (nitrate and pesticide pressures), or forested watershed basins were post-exposed to alachlor at 10 or $30 \mu \mathrm{g} \mathrm{L}^{-1}$ in microcosms (Paule et al. 2014). Alachlor inhibited only the growth of phototrophic biofilms previously cultivated in the less polluted river, indicating the importance of allogenic factors on biofilm susceptibilities. A new prototype of photosynthetic rotating annular reactor (Paule et al. 2011) was constructed for the production of phototrophic biofilms under controlled environmental conditions (physical and chemical parameters and hydrodynamics). Postexposition of these biofilms, having different maturation levels (or biofilm ages) and a drastic diversity 
reduction in their algal and bacterial communities, to alachlor at $10 \mu \mathrm{L} \mathrm{L}^{-1}$ in microcosms allowed to define the effect of biofilm structuration to its alachlor sensitivity (Paule et al. 2013). Alachlor effect was mainly limited to biomass reduction only for younger biofilms (less than 2 weeks of age) without apparent changes in the ecological succession trajectories of bacterial and diatom communities and suggested that carbon utilization spectra of the biofilm are not damaged resulting. By using smaller triplicate rotating annular bioreactors, alachlor at 1 or $10 \mu \mathrm{g} \mathrm{L}^{-1}$ was applied through early stages of biofilm development, from time 0 to 5 weeks (Paule et al. 2015). The results suggested that the concentration-dependent effect of alachlor mainly remains limitedto biomass andgrowth inhibition without apparent changes of ecological succession trajectories and functional characteristics. These researches confirmed the importance of considering the influence of maturation processes or community age when investigating herbicide effects with phototrophic biofilms.

Whether punctual or chronic, oil pollution is a major threat for coastal marine ecosystems. Overall, more than three million tones of oil are spilled each year in coastal ecosystems resulting not only in ecological dysfunction but also in the disruption of local economies (i.e., fishing, aquaculture, tourism). In these coastal ecosystems, the sediment compartment is particularly exposed to this type of contamination due to low hydrocarbon solubility in the aqueous phase, which promotes their accumulation in solid phases such as sediment. To capture the development of microbial consortia, which are indicators of oil contamination, a holistic perspective (Auguet et al. 2010) was adopted (i.e., global geographical distribution of coastal sediment samples and use of public databases) in association with comparative statistical methods (i.e., network analysis). Overall, the ultimate goal of this work is to better predict the ecological consequences of chronic oil contaminations in sediment ecosystems and discover new microbial consortia useful for remediation strategy. Aside biofilm communities, a particular population may be sued for the construction of biosensors targetinghydrophobicorganiccarbon(HOC). The marine model bacterium Marinobacter hydrocarbonoclasticus SP17 that adheres and forms biofilms onto metabolizable HOCs was used to construct a microbial biosensor that emits fluorescence after $2 \mathrm{~h}$ in response to the presence of hexadecane thanks to an inducible reporter gene coding for a yellow fluorescent protein.

Studies were devoted to characterize the modes and pathways of biotransformation of biogenic and/or anthropogenic hydrocarbons in environments where the conditions may not favor the degradation of such hydrophobic organic compounds including anoxia (e.g., anoxic sediments and basins), high hydrostatic pressure (e.g., deep-sea ecosystems, petroleum reservoirs), high temperature (e.g., hydrothermal sites, petroleum reservoirs), and high salinity (e.g., hypersaline ponds and basins).

Complex isoprenoid hydrocarbons are ubiquitous in the marine environment. The formation of pristane (2,6,10,14tetramethylpentadecane) occurs in anoxic sediments (Rontani and Bonin 2011). The question arose about the role played by anaerobic bacteria in these processes. The formation of this hydrocarbon during anaerobic biodegradation of trimmers resulting from the abiotic degradation of vitamin E was confirmed (Rontani et al. 2010). These results confirm that the ratio pristane to phytane cannot be used as an indicator of the toxicity of the environment of deposition. Anaerobic degradation of mixtures of isomeric pristenes by sedimentary bacterial communities was also investigated (Rontani et al. 2013). These isoprenoid alkenes were quickly metabolized without formation of the 
corresponding alkanes. Identification of several bacterial metabolites allowed to confirm the key role played by hydration reactions in the metabolism of alkenes. Biohydrogenation processes did not act significantly on the double bond of pristenes. This resistance was attributed to the lack of binding polar group(s) to anchor the substrate to the enzyme and thus allow the double bond to reach the reductive catalytic site. It therefore seems that microbial hydrogenation of pristenes does not account for the presence of pristane in recent sediments during early diagenesis.

An important challenge is to describe the microorganisms involved in hydrocarbon biodegradation under severe environmental conditions such as high salinity, high pressure, and high temperature. To do so, different experimental approaches (e.g., isolation of pure extremophilic hydrocarbondegrading strains, cultivation of microbial populations or strains under varying physicochemical conditions, in situ incubation of oil contaminated sediments at 2,400 m water depth) and complementary techniques of microbiology, organic geochemistry, and microbial ecology (e.g., mass spectrometry, isotope labeling, DGGE, qRT-PCR, etc.) have been combined. Results indicate the existence of a wide diversity of extremophilic Bacteria and Archaea able of growing on hydrocarbons (i.e., hydrocarbonoclastic microorganisms) by using original degradation pathways. The degradation of unsaturated and saturated alkanes by different types of sulfatereducing microorganisms (Grossi et al. 2011; Hakil et al. 2014), including a hyperthermophilic archaeon widespread in petroleum reservoirs (Khelifi et al. 2010a, b, 2014), has been documented. The diversity of hydrocarbonoclastic microorganisms adapted to high salinity (Tapilatu et al. 2010a) or high hydrostatic pressure (Tapilatu et al. 2010b) and some original strategies to use hydrocarbons under such harsh environmental conditions (Grossi et al. 2010; Silva et al. 2010; Djeridi et al. 2013) were also highlighted. Clearly, the capacity of extremophiles to grow on hydrocarbons still remains underestimated and undoubtedly deserves further attention for many ecological, geochemical, environmental, and biotechnological reasons.

Marine litters consist of $70-80 \%$ of plastic, which undergo a very slow physical, chemical, and biological degradation in seawaters. Several groups of heterotrophic bacteria have been isolated for their capacity to degrade different class of plastics, but these studies were based on few bacteria able to grow on culture media, which represent less than $1 \%$ of the natural diversity. Other works using more recent pyrosequencing approaches investigated the bacteria living in the so-called plastisphere but without being able to evaluate their capability to degrade the plastics. The characterization of the prokaryotic communities (Bacteria and Archaea) associated with the colonization and the degradation of three classes of plastics, which are classically found in marine litters, i.e., polyethylene terephthalate, polyethylene, and polypropylene, was undertaken. The expected results will allow to better understand the microbial ecology of the plastisphere and to discover new prokaryotic species able to degrade different class of plastics in marine waters.

\section{Conclusions}

Microbes, the most diversified and ancient organisms on Earth, are key actors of ecosystem functioning. They contribute (i) to the global biogeochemical cycling of elements essential for life, (ii) 
to the remodeling of landscape and climate over short-term and long-term periods, and (iii) to dynamic of biodiversity. Microbes have been used for centuries by humans for agriculture and food production, more contemporarily for pollutant recycling and soon in a near future for energy production and ecological engineering. Paradoxically, at the exception of human health purposes, the microbial diversity, functioning, dynamics, interaction, and evolution under environmental changes are still poorly explored fields of research.

Recently, technological advances such as the highthroughput analyses of molecules (DNA, RNA, proteins, metabolites) and organisms (single-cell analysis) and imagery and bioinformatictoolspropelledenvironmentalmicrobiologytothe front line of the fast-moving and highly competitive researches. Biogeography is investigating microbial populations and communities at a large scale for understanding their functioning, dynamics, and evolution in present and past ecosystems. Integrative studies of microbial interactions are exploring the complexityand diversity of organism relationships (including microbial sensing and signal transduction) at the level of the cell, the population, the community, and the holobiont. Living microbes and microbial components and activities are now being used as factories, sensors, and indicators for scientific and economic purposes. Environmental microbiology is now really taking off as a scientific discipline by itself. 


\section{The Microbial Ecology EC2CO consortium:}

Pierre Amato Institut de Chimie de Clermont-Ferrand, UMR6296 CNRS, Université Blaise Pascal-Ecole Nationale Supérieure de Chimie de Clermont-Ferrand, 63171 Aubière, France

Florence Arsène-Ploetze Ecophysiologie Moléculaire des Microorganismes, UMR7156, CNRS, Université de Strasbourg, 28 rue Goethe, 67000 Strasbourg, France

Jean-Christophe Auguet UMR CNRS 5254 IPREM, Equipe Environnement et Microbiologie IBEAS BP1155, 64013 Pau Cedex, France

Laetitia Bernard Institut de Recherche pour le Développement (IRD), UMR 210 Eco\&sols, Laboratoire des Radio-Isotopes (LRI), BP 3383, Antananarivo 101, Madagascar

Philippe N. Bertin Ecophysiologie Moléculaire des Microorganismes, UMR7156, CNRS, Université de Strasbourg, 28 rue Goethe, 67000 Strasbourg, France

Yvan Bettarel ECOSYM UMR 5119, IRD, CNRS, Université Montpellier 1 et 2, Université Montpellier 2, 34095 Montpellier cedex 5, France

Aurélie Bigot-Clivot Université Reims Champagne Ardenne, UMR-I 02, Stress Environnementaux et biosurveillance des milieux aquatiques (SEBIO), UFR Sciences Exactes et Naturelles, Moulin de la Housse BP 1039, 51687 Reims Cedex, France

Nicolas Blot Laboratoire Microorganismes, Génome et Environnement, UMR6023 CNRS-UBP-UdA, Université Blaise Pascal, 63171 Aubière Cedex, France

Manuel Blouin Institut d'Ecologie et des Sciences de l'Environnement de Paris (IEES-Paris), UMR 7618, Sorbonne Universities, UPMC Univ. Paris 06, Université Paris-Est Créteil, AgroParisTech, 4 place Jussieu 75252 Paris cedex 05, France

Myriam Bormans UMR 6553 ECOBIO, Université de Rennes 1 CNRS, Campus de Beaulieu, 35042 Rennes Cedex, France

Marc Bouvy ECOSYM UMR 5519, IRD, CNRS, Université Montpellier 1 et 2, Université Montpellier 2, 34095 Montpellier cedex 5, France

Odile Bruneel, Laboratoire HydroSciences Montpellier, UMR HSM 5569, (IRD, CNRS, UM) Université Montpellier, Bâtiment 40, CCMSE, 34095 Montpellier cedex 05, France

Aurélie Cébron Laboratoire Interdisciplinaire des Environnements Continentaux (LIEC), UMR7360 CNRS-Université de Lorraine, Faculté des Sciences et Technologies, BP70239, 54506 Vandoeuvreles-Nancy, France

Urania Christaki UMR LOG 8187, Univ. Lille Nord - Univ. Du Littoral, Wimereux, France Ivan Couée UMR 6553 ECOBIO, Université de Rennes 1 - CNRS, Campus de Beaulieu, 35042 Rennes Cedex, France

Cristiana Cravo-Laureau Equipe Environnement et Microbiologie, MELODY group, Université de Pau et des Pays de l'Adour, IPREM UMR CNRS 5254, BP 1155, 64013 Pau Cedex, France

Michael Danger Laboratoire Interdisciplinaire des Environnements Continentaux (LIEC), UMR 7360, Université de Lorraine-CNRS, Campus Bridoux, rue Claude Bernard, 57070 Metz, France

Julien de Lorgeril ECOSYM (Ecologie des Sytèmes Marins Côtiers), CNRS, Ifremer, IRD, Universités de Montpellier 1 et 2, UMR 5119, 34095 Montpellier Cedex 5, France 
Yves Desdevises UMR 7232 Biologie Intégrative des Organismes Marins (BIOM), Observatoire Océanologique de Banyuls (OOB), Université Pierre et Marie Curie, Avenue du Fontaulé, 66650 Banyuls-sur-Mer, France

Yves Dessaux Institut de Biologie Intégrative de la cellule, CNRS, CEA, Université Paris-Sud, Saclay Plant sciences, 91198 Gif-sur-Yvette, France

Delphine Destoumieux-Garzón ECOSYM (Ecologie des Sytèmes Marins Côtiers), CNRS, Ifremer, IRD, Universités de Montpellier 1 et 2, UMR 5119, 34095 Montpellier Cedex 5, France

Elodie Duprat Institut de Minéralogie, de Physique des Matériaux, et de Cosmochimie (IMPMC) Sorbonne Universités - UPMC Univ. Paris 06, UMR CNRS 7590, Muséum National d'Histoire Naturelle, UR 206, 4 Place Jussieu, 75005 Paris, France

Gaël Erauso Aix-Marseille Université, Mediterranean Institute of Oceanography (MIO), 13288, Marseille, Cedex 9; Université du Sud Toulon-Var, 83957, CNRS-INSU/IRD UM 110, France

Feth el Zahar Haichar UMR-CNRS 5557 Ecologie microbienne, INRA USC 1364, 69100 Villeurbanne, France

Eric Fouilland UMR 5119 ECOSYM - CNRS, University Montpellier 2, University Montpellier 1, IRD, IFREMER, Station Méditerranéenne de l'environnement Littoral, 34200 Sète, France

André-Jean Francez UMR 6553 ECOBIO, Université de Rennes 1 CNRS, Campus de Beaulieu, 35042 Rennes Cedex, France

Nathalie Fromin Centre d'Ecologie Fonctionnelle et Evolutive, UMR 5175, 1919 route de Mende, 34293 Montpellier Cedex 5, France

Alain Geffard Université Reims Champagne Ardenne, UMR-I 02, Stress Environnementaux et biosurveillance des milieux aquatiques (SEBIO), UFR Sciences Exactes et Naturelles, Moulin de la Housse BP 1039, 51687 Reims Cedex, France

Jean-François Ghiglione, CNRS, UMR 7621, Laboratoire d'Océanographie Microbienne (LOMIC), Observatoire Océanologique, 66650 Banyuls/mer, France

Vincent Grossi, Laboratoire de Géologie de Lyon (LGLTPE UMR 5276 CNRS), Université Claude Bernard Lyon 1 - Université de Lyon, campus de la Doua, 69622 Villeurbanne, France.

Katell Guizien, CNRS, Laboratoire d'Ecogéochimie des Environnements Benthiques (LECOB UMR8222), Observatoire Océanologique de Banyuls, 66650 Banyuls-sur-mer, France.

Cédric Hubas, Unité Biologie des Organismes et Écosystèmes Aquatiques (BOREA, UMR 7208), Sorbonne Universités, Muséum National d'Histoire Naturelle, Université Pierre et Marie Curie, Université de Caen Basse-Normandie, CNRS, IRD, Université des Antilles et de la Guyane ; CP53, 61 rue Buffon 75005 Paris, France.

Arnaud Huguet Sorbonne Universités, UPMC Univ Paris 06, CNRS, EPHE, UMR 7619 METIS, 4 place Jussieu, 75252 Paris cedex, France

Ludwig Jardillier Université Paris-Sud, Laboratoire d'Ecologie, Systématique et Evolution, UMR CNRS 8079, bâtiment 360, 91405 Orsay cedex, France

Pascal Jouquet, IRD, UMR CNRS 7618 iEES Paris, IFCWS, Civil engineering Department, Indian Institute of Science, 560012 Bangalore, India

Fabien Joux, Sorbonne Universités, UPMC Univ Paris 06, CNRS UMR 7621, Laboratoire d'Océanographie Microbienne, Observatoire Océanologique, 66650 Banyuls-sur-mer, France 
Aurore Kaisermann, Institut d'Ecologie et des Sciences de l'Environnement de Paris (IEES-Paris), UMR 7618, Sorbonne Universities, UPMC Univ. Paris 06, Université Paris-Est Créteil, AgroParisTech, 4 place Jussieu 75252 Paris cedex 05, France

Oliver Kaltz,Institut des Sciences de I'Evolution, UMR 5554, Université de Montpellier, 34095 Montpellier Cedex 05, France

Jean-Christophe Lata Institut d'Ecologie et des Sciences de l'Environnement de Paris (IEES-Paris), UMR 7618, Sorbonne Universities, UPMC Univ. Paris 06, Université Paris-Est Créteil, AgroParisTech, 4 place Jussieu 75252 Paris cedex 05, France

Antoine Lecerf EcoLab - Laboratoire d'écologie fonctionnelle et environnement UMR 5245 CNRS-INPT-

Université Paul Sabatier, 31062 Toulouse cedex, France

Corinne Leyval Laboratoire Interdisciplinaire des Environnements Continentaux (LIEC), UMR7360 CNRS-Université de Lorraine, Faculté des Sciences et Technologies, BP70239, 54506 Vandoeuvreles-Nancy, France

Patricia Luis Ecologie Microbienne, UMR CNRS 5557, USC INRA 1364, Université de Lyon, Université Lyon 1, 69622 Villeurbanne Cedex, France

Estelle Masseret, Biodiversité Marine, Exploitation \& Conservation, UMR Marbec 9190, IRD-Université de Montpellier-Ifremer-CNRS, cc93, Place Eugène Bataillon, Montpellier cedex 5, France

Audrey Niboyet Institut d'Ecologie et des Sciences de l'Environnement de Paris (IEES-Paris), UMR 7618, Sorbonne Universities, UPMC Univ. Paris 06, Université Paris-Est Créteil, AgroParisTech, 4 place Jussieu 75252 Paris cedex 05, France

Philippe Normand Ecologie Microbienne UMR CNRS5557, Université Lyon1, 69622 cedex Villeurbanne,

France

Frédéric Plewniak Ecophysiologie Moléculaire des Microorganismes, UMR7156, CNRS Université de Strasbourg, 28 rue Goethe, 67000 Strasbourg, France

Franck Poly UMR-CNRS 5557 Ecologie microbienne, INRA USC 1364, 69100 Villeurbanne, France

Soizic Prado, Unité Molécules de Communication et Adaptation des Micro-organismes (MCAM, UMR

7245), Sorbonne Universités, Muséum National d'Histoire Naturelle, CNRS, CP54 ; 63 rue Buffon 75005 Paris, France

Achim Quaiser Université de Rennes 1 - CNRS, UMR 6553 ECOBIO, Campus de Beaulieu, 35042 Rennes cedex, France

Pascal Ratet, Institut of Plant Sciences Paris-Saclay (IPS2), UMR 9213/UMR1403, CNRS, INRA, Université Paris-Sud, Université d'Evry, Université Paris-Diderot, Sorbonne Paris-Cité, Bâtiment 630, 91405 Orsay, France

Agnès Richaume, Ecologie Microbienne, UMR CNRS 5557, Lyon 1, Université de Lyon, 69622 Villeurbanne cedex, France

Jean-Luc Rolland IFREMER, Université Montpellier 2, Centre National de la Recherche Scientifique, IRD, UM1, UMR 5119 Ecologie des Systèmes Marins Côtiers, 34095 Montpellier cedex 5, France Jean-Luc Rols Université Toulouse 3, UMR CNRS 5245 EcoLab, 31062 Toulouse cedex 9, France Jean-François Rontani Aix-Marseille Université, Mediterranean Institute of Oceanography (MIO), 13288, Marseille, Cedex 9; Université du Sud Toulon-Var, 83957, CNRS-INSU/IRD UM 110, France Francesca Rossi UMR5119, Université de Montpellier 2 PI. E. Bataillon Bat 24, 34075 Montpellier, France 
Sophie Sablé Littoral Environnement et Sociétés (LIENSS), UMR 7266 CNRS Université de La Rochelle, UFR Sciences, Bât. Marie Curie, 17042 La Rochelle cedex 01, France

Pierre Sivadon UMR CNRS 5254 IPREM, Equipe Environnement et Microbiologie IBEAS - BP1155, 64013

Pau cedex, France

Philippe Soudant Laboratoire des Sciences de I'Environnement Marin (LEMAR), UMR6539 UBO-CNRS-

IRDIFREMER, Institut Universitaire Européen de la Mer (IUEM), Technopole Brest Iroise, Rue

Dumont d'Urville, 29280 Plouzané, France

Christian Tamburini Aix-Marseille Université, Mediterranean Institute of Oceanography (MIO), 13288,

Marseille, Cedex 9; Université du Sud Toulon-Var, 83957, CNRS-INSU/IRD UM 110, France

Aline Tribollet UMR IPSL-LOCEAN, Centre IRD France Nord, 93143 Bondy Cedex, France

Claire Valiente Moro UMR CNRS 5557, USC INRA 1364, Ecologie Microbienne, Université de Lyon,

Université Lyon 1, 69622 Villeurbanne Cedex, France

France Van Wambeke Aix-Marseille Université, Mediterranean Institute of Oceanography (MIO),

13288, Marseille, Cedex 9; Université du Sud Toulon-Var, 83957, CNRS-INSU/IRD UM 110, France

Philippe Vandenkoornhuyse UMR 6553 ECOBIO, Université de Rennes 1 - CNRS, Campus de Beaulieu,

35042 Rennes Cedex, France

Stéphane Vuilleumier UMR 7156 UdS- CNRS Génétique Moléculaire, Génomique, Microbiologie, 67083

Strasbourg cedex, France

\section{Acknowledgments}

This work is supported by the CNRS Mission pour l'Interdisciplinarite and the Incentive Action Ecosphère Continentale et Côtière (EC2CO). We thank the present and former members of Microbial Ecology EC2CO scientific committee. 


\section{References}

Alloisio N, Queiroux C, Fournier P, Pujic P, Normand P, Vallenet D, Médigue C, Yamaura M, Kakoi K, Kucho KI (2010) The Frankia alni symbiotic transcriptome. Mol Plant Microb Interact 23:593-607 Amossé J, Bettarel Y, Bouvier C, Bouvier T, Tran Duc T, Doan Thu T, Jouquet P (2013) The flows of nitrogen, bacteria and viruses from the soil to water compartments are influenced by earthworm activity and organic fertilization (compost vs. vermicompost). Soil Biol Biochem 66:197-203

Anderson DM, Alpermann TJ, Cembella AD, Collos Y, Masseret E, Montresor M (2012) The globally distributed genus Alexandrium: multifaceted roles in marine ecosystems and impacts on human health. Harmful Algae 14:10-35

Arce Funck J, Clivot H, Felten V, Rousselle P, Guerold F, Danger M (2013a) Phosphorus availability modulates the toxic effect of silver on aquatic fungi and leaf litter decomposition. Aquat Toxicol 144:199-207

Arce Funck J, Danger M, Gismondi E, Cossu-Leguille C, Guérold F, Felten V (2013b) Behavioural and physiological responses of Gammarus fossarum (Crustacea Amphipoda) exposed to silver. Aquat Toxicol 142-143:73-84

Arce Funck J, Bec A, Perrière F, Felten V, Danger M (2015) Aquatic hyphomycetes: a potential source of polyunsaturated fatty acids in detritus-based stream food webs. Fungal Ecol 13:205-210

Arsene-Ploetze F, Carapito C, Plewniak FNP (2012) Proteomics as a tool for the characterization of microbial isolates and complex communities. In: Proteomic applications in biology, Heazlewood $\mathrm{J}(\mathrm{ed}), \ln$ Tech

Arsène-Ploetze F, Bertin P N, Carapito C (2015) Proteomic tools to decipher microbial community structure and functioning. Environ Sci Pollut Res Int. 2014 Dec 5 in press

Auguet JC, Barberan A, Casamayor EO (2010) Global ecological patterns in uncultured Archaea. ISME J 4:182-190

Barbi F, Bragalini C, Vallon L, Prudent E, Dubost A, Fraissinet-Tachet L, Marmeisse R, Luis P (2014) PCR primers to study the diversity of expressed fungal genes encoding lignocellulolytic enzymes in soils using high-throughput sequencing. PLoS ONE 9, e116264

Bardon C, Piola F, Bellvert F, Haichar FZ, Comte G, Meiffren G, Pommier T, Puijalon S, Tsafack N, Poly F (2014) Evidence for biological denitrification inhibition (BDI) by plant secondary metabolites. New Phytol 204(3):620-630

Bernard L, Chapuis-Lardy L, Razafimbelo T, Razafindrakoto M, Pablo AL, Legname E, Poulain J, Brüls T, O’Donohue M, Brauman A, Chotte JL, Blanchart E (2012) Endogeic earthworms shape bacterial functional communities and affect organic matter mineralization in a tropical soil. ISME J 6:213222

Bettarel Y, Nguyen TT, Tran QH, Phan KH, Bouvier T (2013) Observation of virus-like particles in thin sections of the bleaching scleractinian Acropora cytherea. J Mar Biol Ass UK 93:909-912

Bettarel Y, Bouvier T, Nguyen HK, Pham TT (2015) The versatile nature of coral-associated viruses. Environ Microbiol. doi:10.1111/14622920.12579

Blanchet M, Pringault O, Bouvy M, Catala P, Oriol L, Caparros J, OrtegaRetuerta E, Intertaglia L, West $N$, Agis $M$, Got $P$, Joux $F(2015)$ Changes in bacterial community metabolism and composition 
during the degradation of dissolved organic matter from the jellyfish Aurelia aurita in a Mediterranean coastal lagoon. Environ Sci Pollut Res (this issue) doi:10.1007/s11356-014-3848$x$

Bragalini C, Parisot N, Ribière C, Vallon L, Prudent E, Peyretaillade E, Girlanda M, Peyret P, Marmeisse $R$, Luis $P$ (2014) Solution hybrid selection capture for the recovery of functional full-length eukaryotic cDNAs from complex environmental samples. DNA Res 21: 685-694

Céa B, Lefèvre D, Chirurgien L, Charrière B, Garcia N, Raimbault P, Ghiglione JF, Eichinger M, Gregori G, Barani A, Van Wambeke $F$ (2014) An annual survey of bacterial production, respiration and ectoenzyme activity in coastal NW Mediterranean waters: temperature and resource controls. Environ Sci Pollut Res. This special issue

Céa B, Van Wambeke F, Lefèvre D, Chirurgien, L How (2015) Temperature and resource affect marine heterotrophic bacteria activity: a seasonal study in the Bay of Marseille. Aquat Microb Ecol. In press

Cébron A, Beguiristain T, Faure P, Norini M-P, Masfaraud J-F, Leyval C (2009) Influence of vegetation on the in situ bacterial community and polycyclic aromatic hydrocarbon (PAH) degraders in aged PAH-contaminated or thermal-desorption-treated soil. Appl Environ Microbiol 75:6322-6330

Cébron A, Cortet J, Criquet S, Biaz A, Calvert V, Caupert C, Pernin C, Leyval C (2011) Biological functioning of PAH-polluted and thermal-desorption treated soils assessed by fauna and microbial bioindicators. Res Microbiol 162:896-907

Cébron A, Faure P, Ouvrard S, Lorgeoux C, Leyval C (2013) Experimental increase in availability of a PAH complex organic contamination from an aged contaminated soil: consequences on biodegradation. Environ Pollut 177:98-105

Cébron A, Beguiristain T, Bongoua-Devisme J, Denonfoux J, Faure P, Lorgeoux C, Ouvrard S, Peyret P, Leyval C (2015) Impact of clay mineral, wood sawdust or root organic matter on the bacterial and fungal community structures in two aged PAH-contaminated soils. Environ Sci Pollut Res. This special issue

Christaki U, Courties C, Massana, Catala P, Lebaron P, Gasol J, Zubkov MV (2011) Optimized routine flow cytometric enumeration of heterotrophic flagellates using SYBR Green I. Limnol Oceanogr Methods 9:329-339

Christaki U, Kormas KA, Genitsaris S, Georges C, Sime-Ngando T, Viscogliosi E, Monchy S (2014) Wintersummer succession of unicellular eukaryotes in a meso-eutrophic coastal system. Microb Ecol 67:13-23

Cirou A, Raffoux A, Diallo S, Latour X, Dessaux Y, Faure D (2011) Gamma-caprolactone stimulates growth of quorum-quenching Rhodococcus populations in a large-scale hydroponic system for culturing Solanum tuberosum. Res Microbiol 162:945-950

Cirou A, Mondy S, An S, Charrier A, Sarrazin A, Thoison O, DuBow M, Faure D (2012) Efficient biostimulation of native and introduced quorum-quenching Rhodococcus erythropolis populations is revealed by a combination of analytical chemistry, microbiology, and pyrosequencing. Appl Environ Microbiol 78:481-492

Clerissi C, Grimsley N, Ogata H, Hingamp P, Poulain J, Desdevises Y (2014a) Unveiling of the diversity of Prasinoviruses (Phycodnaviridae) in marine samples by using high-throughput sequencing 
analyses of PCR-amplified DNA polymerase and major capsid protein genes. Appl Environ Microbiol 80(10):3150-3160. doi:10.1128/AEM.00123-14

Clerissi C, Grimsley NH, Subirana L, Maria E, Oriol L, Ogata H, Moreau H, Desdevises Y (2014b) Prasinovirus distribution in the Northwest Mediterranean Sea is affected by the environment and particularly by phosphate availability. Virology 466-467:146-157

Coffinet S, Huguet A, Williamson D, Fosse C, Derenne S (2014) Potential of GDGTs as a temperature proxy along an altitudinal transect at Mount Rungwe (Tanzania). Org Geochem 68:82-89

Collos Y, Hadjadji I, Plisson B, Philippe Cecchi P, Laabir M, Bechemin C, Masseret E (2011) Phased oscillations in cell numbers and nitrate in batch cultures of Alexandrium tamarense (Dinophyceae). J Phycol 47:1057-1062

Couée I, Bringel F (2010) Expanding importance of mRNA expression in understanding stress and stress responses. J Theor Biol 266:479-482

Couée I, Serra AA, Ramel F, Gouesbet G, Sulmon C (2013) Physiology and toxicology of hormonedisrupting chemicals in higher plants. Plant Cell Rep 32:933-941

Cravo-Laureau C, Hernandez-Raquet G, Vitte I, Jezequel R, Belet V, Godon JJ, Caumette P, Balaguer P, Duran R (2011) Role of environmental fluctuations and microbial diversity in degradation of hydrocarbons in contaminated sludge. Res Microbiol 162:888-895

D’Angelo-Picard C, Chapelle E, Ratet P, Faure D, Dessaux Y (2011) Transgenic plants expressing the quorum quenching lactonase AttM do not significantly alter root-associated bacterial populations. Res Microbiol 162:951-958

Danger M, Chauvet E (2013) Elemental composition and degree of homeostasis of fungi: are aquatic hyphomycetes more like metazoans, bacteria, or plants? Fungal Ecol 6:453-457

Danger M, Arce Funck J, Devin S, Heberlé J, Felten V (2013a) Phosphorus content in detritus controls life history traits of a detritivore. Funct Ecol 27:807-815

Danger M, Cornut J, Chauvet E, Chavez P, Elger A, Lecerf A (2013b) Benthic algae stimulate leaf litter decomposition a detritus-based headwater streams: a case of aquatic priming effect? Ecology 94: 1604-1613. doi:10.1890/12-0606.1

Djeridi I, Militon C, Grossi V, Cuny P (2013) Evidence for surfactant production by the haloarchaeon Haloferax sp MSNC14 in hydrocarbon-containing media. Extremophiles 17:669-675

Duncan AB, Fellous S, Accot R, Alart M, Chantung Sobandi K, Cosiaux A, Kaltz O (2010) Parasitemediated protection against osmotic stress for Paramecium caudatum infected by Holospora undulata is host genotype specific. FEMS Microbiol Ecol 74:353-360

Duncan AB, Fellous S, Kaltz O (2011a) Temporal variation in temperature determines disease spread and maintenance in Paramecium microcosm populations. Proc R Soc B 278:3412-3420

Duncan AB, Fellous S, Quillery E, Kaltz O (2011b) Adaptation of Paramecium caudatum to variable conditions of temperature stress. Res Microbiol 162:939-944

Durrieu C, Guedri H, Fremion F, Volatier L (2011) Unicellular algae used as biosensors for chemical detection in Mediterranean lagoon and coastal waters. Res Microbiol 162:908-914

El Azzi D, Viers J, Guiresse M, Probst A, Aubert D, Caparros J, Charles F, Guizien K, Probst JL (2013) Copper fate in a small Mediterranean vineyard catchment: coupling chemical extraction and 865Cu isotopic signature approaches. Sci Total Environ 463-464:91-101 
Fanin N, Barantal S, Fromin N, Schimann H, Schevin P, Hättenschwiler S (2012) Distinct microbial limitations in litter and underlying soil revealed by carbon and nutrient limitations in a tropical rainforest. PLoS ONE 7, e49990

Fanin N, Fromin N, Buatois B, Hättenschwiler S (2013) An experimental test of the hypothesis of nonhomeostatic consumer stoichiometry in a plant litter-microbe system. Ecol Lett 16:764-772

Fanin N, Hättenschwiler S, Fromin N (2014) Litter fingerprint on microbial biomass, activity, and community structure in the underlying soil. Plant Soil 379:79-91

Fanin N, Hättenschwiler S, Schimann H, Fromin N (2015) Interactive effects of C, N, and P fertilization on soil microbial community structure and function in an Amazonian rainforest. Funct Ecol 29: 140-150

Farhan UI Haque M, Nadalig T, Bringel F, Schaller H, Vuilleumier S (2013) Fluorescence-based bacterial bioreporter for specific detection of methyl halide emissions in the environment. Appl Environ Microbiol 79:6561-6567

Fouilland E, Trottet A, Bancon-Montigny C, Bouvy M, Le Floch' E, Gonzalez J-L, Hatey E, Mas S, Mostajir B, Nouguier J, Pecqueur D, Rochelle-Newall E, Rodier C, Roques C, Salles C, Tournoud MG, Vidussi $F$ (2012) Impact of a river flash flood on microbial carbon and nitrogen production in a Mediterranean Lagoon (Thau Lagoon, France). Estuar Coast Shelf Sci 113:192-204

Genovesi B, Shin-Grzebyk M-S, Grzebyk D, Laabir M, Gagnaire P-A, Vaquer A, Pastoureaud A, Lasserre $B$, Collos Y, Berrebi P, Masseret E (2011) Assessment of cryptic species diversity within blooms and cyst bank of the Alexandrium tamarense complex (Dinophyceae) in a Mediterranean lagoon facilitated by semi-multiplex PCR. J Plankton Res 33(3):405-414

Grange J, Rybarckzyk H, Tribollet A (2015) The three steps of the carbonate biogenic dissolution process by microborers in coral reefs (New Caledonia). Environm Sci Pollut Res. doi:10.1007/s11356014-4069-z, This special issue

Grossi V, Yakimov MM, Al Ali B, Tapilatu Y, Cuny P, Goutx M, La Cono V, Giuliano L, Tamburini C (2010) Hydrostatic pressure affects membrane and storage lipid compositions of the piezotolerant hydrocarbon-degrading Marinobacter aquaeolei strain \#5. Environ Microbiol 12:2020-2033

Grossi V, Cravo-Laureau C, Rontani JF, Cros M, Hirschler-Réa A (2011) Anaerobic oxidation of n-alkenes by sulphate-reducing bacteria from the genus Desulfatiferula: $n$-ketones as potential metabolites. Res Microbiol 162:915-922

Hadjadji I, Masseret E, Plisson B, Laabir M, Cecchi P, Collos Y (2012) Clonal variation in physiological parameters of Alexandrium tamarense: implications for biological invasions and maintenance. Cah Biol Mar 53:357-363

Hakil F, Amin-Ali O, Hirschler-Réa A, Mollex D, Grossi V, Duran R, Matheron R, Cravo-Laureau C (2014) Desulfatiferula berrensis sp nov, a n-alkene degrading sulfate-reducing bacterium isolated from estuarine sediments. Int J Syst Evol Microbiol 64:540-544

Halter D, Cordi A, Gribaldo S, Gallien S, Goulhen-Chollet F, HeinrichSalmeron A, Carapito C, Pagnout C, Montaut D, Seby F, Van Dorsselaer A, Schaeffer C, Bertin PN, Bauda P, Arsène-Ploetze F (2011) Taxonomic and functional prokaryote diversity in mildly arsenic contaminated sediments. Res Microbiol 162:877-887

Heinrich-Salmeron A, Cordi A, Brochier-Armanet C, Halter D, Pagnout C, Abbaszadeh-fard E, Montaut D, Seby F, Bertin PN, Bauda P, Arsène-Ploetze F (2011) Unsuspected diversity of arseniteoxidizing 
bacteria revealed by a widespread distribution of the aoxB gene in prokaryotes. Appl Environ Microbiol 77:4685-4692

Hernandez-Raquet G, Durand E, Braun F, Cravo-Laureau C, Godon JJ (2013) Impact of microbial diversity depletion on xenobiotic degradation by sewage-activated sludge. Environ Microbiol Rep 5:588-594

Hocher V, Alloisio N, Auguy F, Fournier P, Doumas P, Pujic P, Gherbi H, Queiroux C, Da Silva C, Wincker P, Normand P, Bogusz D (2011) Transcriptomics of actinorhizal symbioses reveals homologs of the whole common symbiotic signaling cascade. Plant Physiol 156:1-12

Hubas C, Jesus B, Passarelli C, Jeanthon C (2011) Tools providing new insight into coastal anoxygenic purple bacterial mats: review and perspectives. Res Microbiol 162(9):858-868

Hubas C, Jesus B, Ruivo M, Meziane T, Thiney N, Davoult D, Spilmont N, Paterson DM, Jeanthon C (2013) Proliferation of anoxygenic purple bacteria at the sediment surface affects intertidal biofilm diversity and functionality. PLoS One 8(12), e82329. doi:10.1371/journal.pone.0082329

Jouquet P, Bottinelli N, Podwojewski P, Hallaire V, Tran Duc T (2008) Chemical and physical properties of earthworm casts a compared to bulk soil under a range of different land-use systems in Vietnam. Geoderma 146:231-238

Jouquet P, Zangerlé A, Rumpel C, Brunet D, Bottinelli N, Tran Duc T (2009) Relevance of the biogenic and physicogenic classification. A comparison of approaches to discriminate the origin of soil aggregates. Eur J Soil Sci 60:1117-1125

Jouquet P, Ngo Thi P, Henry-des-Tureaux T, Chevallier T, Trand Duc T (2011) Laboratory investigation of organic matter mineralization and nutrient leaching from earthworm casts produced by Amynthas khami. Appl Soil Ecol 47:24-30

Jouquet P, Maron P-A, Nowak V, Tran Duc T (2013) Utilization of microbial abundance and diversity as indicators of the origin of soil aggregates produced by earthworms. Soil Biol Biochem 57:950952

Kaisermann A, Roguet A, Nunan N, Maron PA, Ostle N, Lata JC (2013) Agricultural management affects the response of soil bacterial community structure and respiration to water-stress. Soil Biol Biochem 66:69-77. doi:10.1016/j.soil.bio.2013.07.001

Kaisermann A, Maron PA, Beaumelle L, Lata J-C (2014) Fungal communities are more sensitive to nonextreme soil moisture variations than bacterial communities. Appl Soil Ecol 86:158-164. doi:10. 1016/jap.soil.2014.10.009

Khelifi N, Ben Romdhane E, Hedi A, Postec A, Fardeau ML, Hamdi M, Tholozan JL, Ollivier B, HirschlerRéa A (2010a) Characterization of Microaerobacter geothermalis gen nov, sp nov, a novel microaerophilic, nitrate- and nitrite-reducing thermophilic bacterium isolated from a terrestrial hot spring in Tunisia. Extremophiles 14: 297-304

Khelifi N, Grossi V, Hamdi M, Dolla A, Tholozan JL, Ollivier B, Hirschler-Réa A (2010b) Anaerobic oxidation of fatty acids and alkenes by the hyperthermophilic sulfate-reducing archaeon Archaeoglobus fulgidus. Appl Environ Microbiol 76:3057-3060

Khelifi N, Amin Ali O, Roche P, Grossi V, Brochier-Armanet C, Valette O, Ollivier B, Dolla A, HirschlerRéa A (2014) Anaerobic oxidation of long-chain n-alkanes by the hyperthermophilic sulfatereducing archaeon, Archaeoglobus fulgidus. ISME J. doi:10.1038/ismej. 2014.58 
Kruger MC, Bertin PN, Heipieper HJ, Arsène-Ploetze F (2013) Bacterial metabolism of environmental arsenic-mechanisms and biotechnological applications. Appl Microbiol Biotechnol 97:38273841

Laabir M, Barré N, Franco J, Brunet C, Masseret E, Collos Y (2012) Morphological, biochemical and growth characteristics of Alexandrium catenella (Whedon and Kofoid) Balech, a toxic dinoflagellate in Mediterranean waters. Cah Biol Mar 53:365-372

Lagrue C, Kominoski JS, Danger M, Baudoin JM, Lamothe S, Lambrigot D, Lecerf A (2011) Experimental shading alters litter breakdown in streams of contrasting riparian canopy cover. Freshw Biol 56:2059- 2069. doi:10.1111/j.1365-2427.2011.02637.x

Laporte M, Shao Z, Berrebi P, Laabir M, Abadie E, Faivre N, Rieuvilleneuve F, Masseret E (2014) Isolation of 12 microsatellite markers following a pyrosequencing procedure and cross-priming in two invasive cryptic species, Alexandrium catenella (group IV) and A. tamarense (group III) (Dinophyceae). Mar Pollut Bull 83:302-305

Lata JC, Kaisermann A (2013) Sols vivants et cycles biogéochimiques. In: Euzen A, Eymard L, Gaill F (eds) Le Développement Durable à Découvert CNRS Editions, Paris, France, pp 80-81 ISBN: 978-227107896-4

Lelong A, Hégaret $H$, Soudant P (2011) Cell-based measurements to assess physiological status of Pseudo-nitzschia multiseries, a toxic diatom. Res Microbiol 162:969-981

Lelong A, Hégaret H, Soudant P, Bates SS (2012a) Pseudo-nitzschia (Bacillariophyceae) species, domoic acid and amnesic shellfish poisoning: revisiting previous paradigms. Phycologia 51:168-216

Lelong A, Jolley D, Hégaret H, Soudant P (2012b) The effects of copper toxicity on Pseudo-nitzschia spp physiology and domoic acid production. Aquat Toxicol 118-119:37-47

Lelong A, Bucciarelli E, Hégaret H, Soudant $P$ (2013) Iron and copper limitations differently affect growth rates, photosynthetic and physiological parameters of the marine diatom Pseudonitzschia delicatissima. Limnol Oceanogr 58(2):613-623

Lelong A, Hégaret $H$, Soudant $P$ (2014) Link between domoic acid production and cell physiology after exchange of bacterial communities between toxic Pseudo-nitzschia multiseries and non-toxic Pseudonitzschia delicatissima. Mar Drugs 12(6):3587-3607

Leruste A, Bouvier T, Bettarel Y (2012) Enumerating viruses in coral mucus. Appl Environ Microbiol 78:6377-6379

Martini S, Nerini D, Tamburini C. Relation between deep bioluminescence and oceanographic variables: a statistical analysis using timefrequency decompositions. Progress in Oceanography in revision

Martini S, Al Ali B, Garel M, Nerini D, Grossi V, Casalot L, Cuny P, Tamburini C (2013) Effects of hydrostatic pressure on growth and luminescence of a moderately-piezophilic luminous bacteria Photobacterium phosphoreum ANT-2200. PLoS ONE 8(6), e66580

Martini S, Nerini D, Tamburini C (2014) Relation between deep bioluminescence and oceanographic variables: a statistical analysis using time-frequency decompositions. Prog Oceanogr 127:117128. doi: 10.1016/j.pocean.2014.07.003

Masseret E, Grzebyk D, Nagai S, Genovesi B, Lasserre B, Laabir M, Collos Y, Vaquer A, Berrebi P (2009) Unexpected genetic diversity among and within populations of the toxic dinoflagellate 
Alexandrium catenella as revealed by nuclear microsatellite markers. Appl Environ Microbiol 75(7):2037-2045

Masseret E, Enquebecq M, Laabir M, Genovesi B, Vaquer A, Avarre J-C (2010) A simple and innovative method for species identification of phytoplankton cells on minute quantities of DNA. Environ Microbiol Rep 2(6):715-719

Medhioub W, Ramondenc S, Vanhove A, Vergnes A, Masseret E, Savar V, Amzil Z, Laabir M, Rolland JL (2013) Exposure to the neurotoxic dinoflagellate Alexandrium catenella induces apoptosis of the oyster Crassostrea gigas hemocytes. Mar Drugs 11:4799-4814

Minard G, Tran FH, Dubost A, Tran Van V, Mavingui P, Valiente Moro C (2014) Pyrosequencing 16S rRNA genes of bacteria associated with wild tiger mosquito Aedes albopictus: a pilot study. Front Cell Infect Microbiol 4:59

Monchy S, Grattepanche J-D, Breton E, Dionigia M, Sanciu G, Chabé M, Delhaes L, Viscogliosi E, SimeNgando T, Christaki U (2012) Micro planktonic community structure in a coastal system relative to a Phaeocystis bloom inferred from morphological and Tag pyrosequencing methods. PLoS ONE 7(6), e39924. doi:10.1371/journal. pone.0039924

Monnin C, Chavagnac V, Boulard C, Menez B, Gérard E, Quéméneur M, Erauso G, Postec A, GuentasDombrowsky L, Payri C, Pelletier B (2014) The low temperature hyperalkaline hydrothermal system of the Prony Bay (New Caledonia). Biogeosciences 11:6221-6267

Nguyen Hong H, Rumpel C, Herny-des-Tureaux T, Bardoux G, Billou D, Trand Duc T, Jouquet P (2011) How do earthworms influence organic matter quality in tropical soil? Soil Biol Biochem 43:223230

Nguyen HK, Bouvier T, Bouvier C, Nhu NH, Nguyen LN, RochelleNewall E, Baudoux A-C, Desnues C, Reynaud S, Ferrier-Pages C, Bettarel Y (2014) High occurrence of viruses in the mucus layer of scleractinian corals. Environ Microbiol Rep 6:675-682

Palos-Ladeiro M, Bigot A, Aubert D, Hohweyer J, Favennec L, Villena I, Geffard A (2013) Protozoa interaction with aquatic invertebrate: interest for water courses biomonitoring. Environ Sci Pollut Res 20:778-789

Palos-Ladeiro M, Aubert D, Villena I, Geffard A, Bigot A (2014) Bioaccumulation of human waterborne protozoa by zebra mussel (Dreissena polymorpha): interest for water biomonitoring. Water Res 48:148-155

Palos-Ladeiro M, Bigot-Clivot A, Aubert D, Villena I, Geffard A (2015) Assessment of Toxoplasma gondii levels in zebra mussel (Dreissena polymorpha) by real time qPCR: an organotropism study. Environ Sci Pollut Res. (Submitted, this special issue)

Pannard A, Bormans M, Lagadeuc Y (2008) Phytoplankton species turnover controlled by physical forcing at different time scales. Can J Fish Aquat Sci 65:47-60

Paule A, Lauga B, Ten-Hage L, Morchain J, Duran R, Paul E, Rols JL (2011) A photosynthetic rotating annular bioreactor (Taylor-Couette type flow) for phototrophic biofilm cultures. Water Res 45(18): 6107-6118

Paule A, Roubeix V, Lauga B, Duran R, Delmas F, Paul E, Rols JL (2013) Changes in tolerance to herbicide toxicity throughout development stages of phototrophic biofilms. Aquat Toxicol 144-145:310321 
Paule A, Lamy A, Roubeix V, Delmas F, Rols JL (2014) Influence of the natural growth environment to the sensitivity of phototrophic biofilm to herbicide. Environ Sci Pollut Res. doi:10.1007/ s11356014-3429-z

Paule A, Roubeix V, Swerhone GDW, Roy J, Lauga B, Duran R, Delmas F, Paul E, Rols JL, Lawrence JR (2015) Comparative responses of river biofilms at the community-level to common organic solvent and herbicide exposure. Environ Sci Pollut Res. This special issue

Pecqueur D, Vidussi F, Fouilland E, Le Floc'h E, Mas S, Roques C, Salles C, Tournoud M-G, Mostajir B (2011) Dynamics of microbial planktonic food web components during a river flash flood in a Mediterranean coastal lagoon. Hydrobiologia 673:13-27

Petit M, Sempéré R, Vaultier F, Rontani J-F (2013) Transfer of photooxidative processes from senescent phytoplankton cells to attached bacteria: formation and behavior of cis-vaccenic photoproducts. Int J Mol Sci 14:11795-11815

Petit M, Bonin P, Amiraux R, Michotey V, Guasco S, Armitano J, JourlinCastelli C, Vaultier F, Méjean V et Rontani J-F (2015b) Effects of singlet oxygen transfer on the dynamic of bacterial communities attached to phytodetritus. Environ Sci Pollut Res. This special issue

Petit M, Suroy M, Sempéré R, Vaultier F, Volkman JK, Goutx M et Rontani J-F (2015a) Transfer of singlet oxygen from senescent phytoplankton cells to attached heterotrophic bacteria: effect of silica and carbonaceous matrices. Mar Chem. (Sous presse)

Poisot T, Lepennetier G, Martinez E, Ramsayer J, Hochberg ME (2010) Resource availability affects the structure of a natural bacteria-bacteriophage community. Biol Lett 7:201-204

Poisot T, Bell T, Martinez E, Gougat-Barbera C, Hochberg ME (2013) Terminal investment induced by a bacteriophage in a rhizosphere bacterium. F1000 Research 1:21

Quaiser A, Bodi X, Dufresne A, Naquin D, Francez A-J, Dheilly A, Coudouel S, Pedrot M, Vandenkoornhuyse $P$ (2014) Unraveling the stratification of an iron-oxidizing microbial mat by metatranscriptomics. PLoS ONE 9(7), e102561. doi:10.1371/journal.pone.0102561

Quéméneur M, Bes M, Postec A, Mei N, Hamelin J, Monnin C, Chavagnac V, Payri C, Pelletier B, Guentas-Dombrowsky L, Gérard M, Pisapia C, Gérard E, Ménez B, Ollivier B, Erauso G (2014) Spatial distribution of microbial communities in the shallow submarine alkaline hydrothermal field of the Prony Bay, New Caledonia. Environ Microbiol Rep. doi:10.1111/1758-2229.12184

Rontani J-F, Bonin P (2011) Formation of pristane and phytane in the marine environment: role of bacteria. Res Microbiol 162:923-933

Rontani J-F, Nassiry M, Guasco S, Michotey V, Bonin P (2010) Production of pristane from tocopherols under simulated anoxic sedimentary conditions: a combination of biotic and abiotic degradative processes. Geochim Cosmochim Acta 74:252-263

Rontani J-F, Bonin P, Vaultier F, Guasco S, Volkman JK (2013) Anaerobic bacterial degradation of pristenes and phytenes in marine sediments does not lead to pristane and phytane during early diagenesis. Org Geochem 58:43-55

Rossi F, Colao E, Martinez MJ, Klein JC, Carcaillet F, Callier MD, Wit R, Caro A (2013) Spatial distribution and nutritional requirements of the endosymbiont-bearing bivalve Loripes lacteus (sensu Poli, 1791) in a Mediterranean Nanozostera noltii meadow. J Exp Mar Biol Ecol. doi:10.1016/j.jembe.2012.12.010 
Roudel M, Aufauvre J, Corbara B, Delbac F, Blot N (2013) New insights on the genetic diversity of the honeybee parasite Nosema ceranae based on multilocus sequence analysis. Parasitology 140: 1346-1356

Sanchez-Ferandin S, Leroy F, Bouget F-Y, Joux F (2013) A new, sensitive marine microalgal recombinant biosensor using luminescence monitoring for toxicity testing of antifouling biocides. Appl Environ Microbiol 79:631-638

Schmitt P, Santini A, Vergnes A, Degremont L, de Lorgeril J (2014) Sequence polymorphism and expression variability of Crassostrea gigas immune related genes discriminate two oyster lines contrasted in term of resistance to summer mortalities. PLoS One 8(9):e75900

Silva RA, Grossi V, Olivera NL, Alvarez HM (2010) Characterization of the indigenous Rhodococcus sp 602, a strain able to accumulate triacylglycerides from naphthyl-compounds under nitrogenstarved conditions. Res Microbiol 161:198-207

Simon M, López-García P, Moreira D, Jardillier L (2013) New haptophyte lineages and multiple independent colonizations of freshwater ecosystems. Environ Microbiol Rep 5:322-332

Simon M, Jardillier L, Deschamps P, Moreira D, Restoux G, Bertolino P, López-García P (2014) Complex communities of small protists and unexpected occurrence of typical marine lineages in shallow freshwater systems. Environ Microbiol. doi:10.1111/1462-2920.12591

Simon M, López-García P, Deschamps P, Moreira D, Restoux G, Bertolino P, Jardillier L (2015) Marked seasonality despite apparent hectic temporal dynamics of complex protist communities in shallow freshwater systems. ISME J. doi:10.1038/ismej.2015.6

Simonin M, Richaume A (2015) Impact of engineered nanoparticles on the activity, abundance and diversity of soil microbial communities: a review. Environ Sci Pollut Res. doi:10.1007/s11356015-4171-x

Simonin M, Guyonnet J, Ginot M, Martins JMF, Richaume A (2015) Influence of soil properties on the toxicity of $\mathrm{TiO}_{2}$ nanoparticles on carbon mineralization and bacterial abundance. J Hazard Mater 283:529-535

Tamburini C, Canals M, Durieu de Madron X, Houpert L, Lefèvre D, Martini S, D'Ortenzio F, Robert A, Testor $P$, the ANTARES collaboration (2013) Deep-sea bioluminescence blooms after dense water formation at the ocean surface. PLoS ONE 8(7):e67523

Tannières M, Beury-Cirou A, Vigouroux, Mondy S, Pellissier F, Dessaux Y, Faure D (2013) A metagenomic study highlights phylogenetic proximity of quorum-quenching and xenobioticdegrading amidases of the AS-family. PLoS ONE 8, e65473

Tapilatu Y, Acquaviva M, Guige C, Miralles G, Bertrand JC, Cuny P (2010a) Isolation of alkane-degrading bacteria from deep-sea Mediterranean sediments. Lett Appl Microbiol 50:234-236

Tapilatu Y, Grossi V, Acquaviva M, Militon C, Bertrand JC, Cuny P (2010b) Isolation of hydrocarbondegrading extremely halophilic archaea from an uncontaminated hypersaline pond (Camargue, France). Extremophiles 14:225-231

Thion C, Cébron A, Beguiristain T, Leyval C (2012) Long-term in situ dynamics of the fungal communities in a multi-contaminated soil are mainly driven by plants. FEMS Microbiol Ecol 82:169-181

Tribollet A, Godinot C, Atkinson M, Langdon C (2009) Effects of elevated pCO2 on dissolution of coral carbonates by microbial euendoliths. Glob Biogeochem Cycles 23, GB3008. doi:10.1029/ 2008GB003286 
Trottet A, Fouilland E, Leboulanger C, Lanouguère E, Bouvy M (2011) Use of inhibitors for coastal bacteria and phytoplankton: application to nitrogen uptake rates. Estuar Coast Shelf Sci 93:151159

Vandenkoornhuyse P, Dufresne A, Quaiser A, Gouesbet G, Binet F, Francez AJ, Mahe S, Bormans M, Lagadeuc Y, Couée I (2010) Integration of molecular functions at the ecosystemic level: breakthroughs and future goals of environmental genomics and post-genomics. Ecol Lett 13:776-791

Verbruggen H, Tribollet A (2011) Boring algae. Curr Biol 21(21):R876- R877. doi:10.1016/j.cub.2011.09.014

Vitte I, Duran R, Jezequel R, Caumette P, Cravo-Laureau C (2011) Effect of oxic/anoxic switches on bacterial communities and PAH biodegradation in an oil-contaminated sludge. Environ Sci Pollut Res 18: 1022-1032

Vitte I, Duran R, Hernandez-Raquet G, Mounier J, Jezequel R, Bellet V, Balaguer P, Caumette P, CravoLaureau C (2013) Dynamics of metabolically active bacterial communities involved in $\mathrm{PAH}$ and toxicity elimination from oil-contaminated sludge during anoxic/oxic oscillations. Appl Microbiol Biotechnol 97:4199-4211

Zhang SD, Barbe V, Garel M, Zhang W-J, Chen H, Santini C-L, Murat D, Jing H, Zhao Y, Lajus A, Martini S, Pradel N, Tamburini C, Wu L-F (2014) Genome sequence of luminous piezophile Photobacterium phosphoreum ANT-2200. Genome Announc 2(2):e00096-00014 